\title{
Roles of Eph-Ephrin Signaling in the Eye Lens Cataractogenesis, Biomechanics, and Homeostasis
}

\author{
Subashree Murugan and Catherine Cheng * \\ Indiana University, School of Optometry and Vision Science Program, Bloomington, IN, United States
}

OPEN ACCESS

Edited by:

Sue Menko,

Thomas Jefferson University,

United States

Reviewed by:

Michael Robinson,

Miami University, United States

Linda Musil,

Oregon Health and Science University,

United States

*Correspondence:

Catherine Cheng

ckcheng@iu.edu

Specialty section:

This article was submitted to

Cell Adhesion and Migration,

a section of the journal

Frontiers in Cell and Developmental

Biology

Received: 11 January 2022 Accepted: 04 February 2022

Published: 28 February 2022

Citation:

Murugan S and Cheng C (2022) Roles of Eph-Ephrin Signaling in the Eye Lens

Cataractogenesis, Biomechanics, and Homeostasis.

Front. Cell Dev. Biol. 10:852236. doi: $10.3389 /$ fcell.2022.852236
The eye lens is responsible for fine focusing of light onto the retina, and its function relies on tissue transparency and biomechanical properties. Recent studies have demonstrated the importance of Eph-ephrin signaling for the maintenance of life-long lens homeostasis. The binding of Eph receptor tyrosine kinases to ephrin ligands leads to a bidirectional signaling pathway that controls many cellular processes. In particular, dysfunction of the receptor EphA2 or the ligand ephrin-A5 lead to a variety of congenital and age-related cataracts, defined as any opacity in the lens, in human patients. In addition, a wealth of animal studies reveal the unique and overlapping functions of EphA2 and ephrin-A5 in lens cell shape, cell organization and patterning, and overall tissue optical and biomechanical properties. Significant differences in lens phenotypes of mouse models with disrupted EphA2 or ephrin-A5 signaling indicate that genetic modifiers likely affect cataract phenotypes and progression, suggesting a possible reason for the variability of human cataracts due to Eph-ephrin dysfunction. This review summarizes the roles of EphA2 and ephrin-A5 in the lens and suggests future avenues of study.

Keywords: EphA2, ephrin-A5, fiber cell, epithelial cell, suture

\section{INTRODUCTION}

Eph-ephrin signaling plays an important role in development, homeostasis, and disease in humans (Henkemeyer et al., 1994; Holmberg et al., 2000; Clevers and Batlle, 2006; Zhao et al., 2006) and other organisms (Park et al., 2004; Picco et al., 2007; Lisabeth et al., 2013). This signaling pathway can act bidirectionally to initiate canonical signaling through kinase activity if receptor-ligand interaction occurs in trans on neighboring cells or can bring about non-canonical signaling if the receptors or ligands signal in cis within a single cell (Liang et al., 2019). Several organ systems and diseases influenced by this canonical or non-canonical pathway have been reviewed in detail previously (O'Leary and Wilkinson, 1999; Pasquale, 2004; Himanen et al., 2007; Pasquale, 2008, 2010; Lisabeth et al., 2013; Barquilla and Pasquale, 2015; Kania and Klein, 2016; Darling and Lamb, 2019; Defourny, 2019; Kaczmarek et al., 2021). Recently, disruption of Eph-ephrin signaling in human patients has been associated with congenital and age-related cataracts, defined as any opacity in the transparent eye lens (Shiels et al., 2008; Jun et al., 2009; Zhang et al., 2009; Kaul et al., 2010; Tan et al., 2011; Sundaresan et al., 2012; Dave et al., 2013; Patel et al., 2017; Berry et al., 2018; Zhai et al., 2019). Mouse models are now being used to understand the mechanism of cataractogenesis (Cooper et al., 2008; Jun et al., 2009; Cheng and Gong, 2011; Shi et al., 2012; Cheng et al., 2013; Son et al., 2013; Biswas et al., 2016; Cheng et al., 2017; Cheng et al., 2021; Zhou et al., 2021; Cheng et al., 2022). In this review, we highlight the different functions of Eph-ephrin signaling in the lens, describe how genetic background influences cataract phenotypes, as well as provide some insights into future directions 

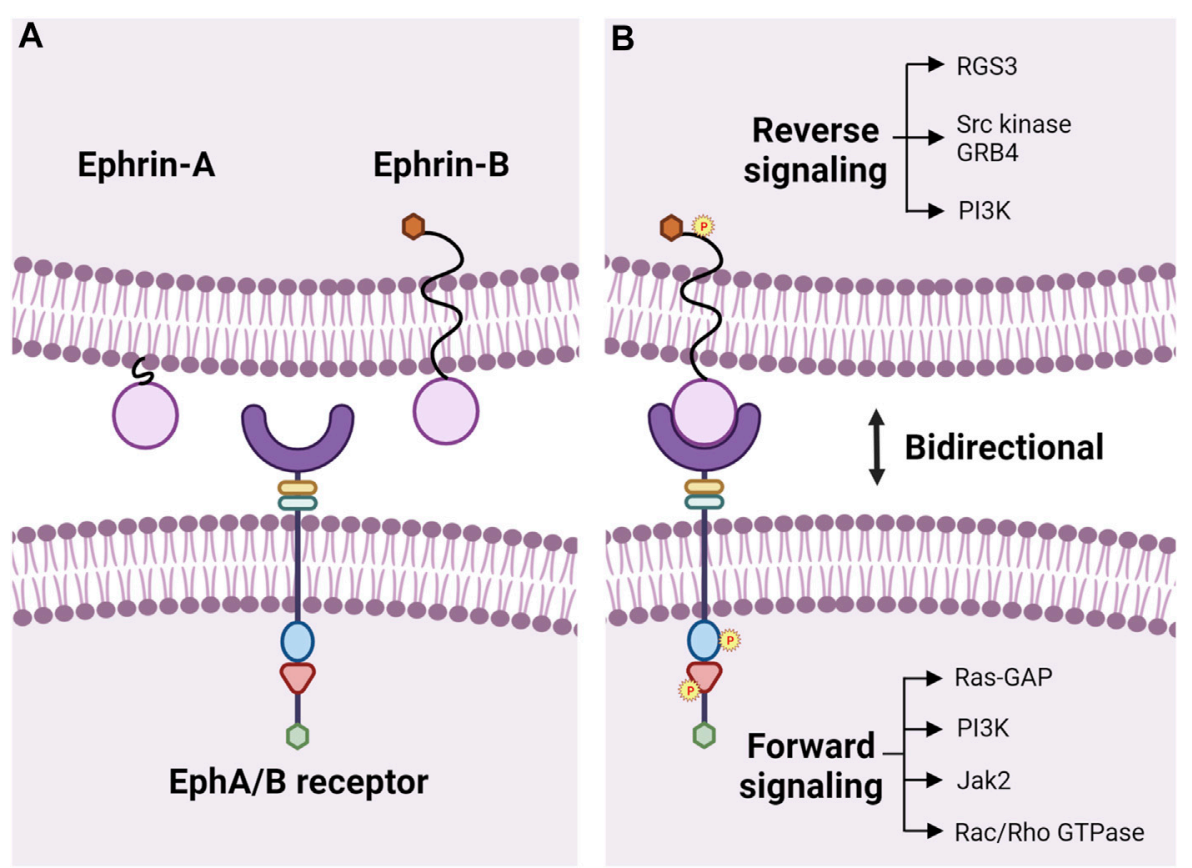

FIGURE 1 | Eph-ephrin bidirectional signaling. (A) Transmembrane Eph receptor tyrosine kinases consist of a ligand binding domain (purple semi-circle), cysteinerich EGF-like motif (yellow rectangle), and fibronectin type III repeats (green rectangle) in the extracellular region and have a tyrosine kinase domain (blue oval), SAM domain (red triangle), and a PDZ-binding motif (green hexagon) intracellularly. The extracellular and intracellular domains are linked by a transmembrane domain. Eph receptors are divided into two classes, EphAs, and EphBs, and bind to membrane-bound ligands called ephrins. Ephrin-As are membrane-anchored via a glycosylphosphatidylinositol (GPI) moiety, and ephrin-Bs have a transmembrane domain with a short cytoplasmic extension containing a PDZ-binding motif (orange hexagon) for autophosphorylation. (B) Binding of Ephs to ephrins leads to bidirectional signaling with forward signaling in the Eph-bearing cell and reverse signaling in the ephrin-bearing cell through phosphorylation of tyrosine residues. Downstream activation of various kinases and pathways has been reviewed in detail previously (Pasquale, 2008). Illustration not drawn to scale and created with the aid of BioRender.com.

and potential therapeutic strategies that can be tested to understand the pathogenesis of age-related cataracts.

\section{Eph-ephrin Bidirectional Signaling}

Erythropoietin-producing hepatocellular carcinoma (Eph) receptors are transmembrane proteins that make up a large subfamily of receptor tyrosine kinases (RTK) (Pasquale, 2010; Pitulescu and Adams, 2010; Darling and Lamb, 2019). Eph receptors interact with cell surface-bound ligands, known as Eph receptor-interacting proteins (ephrins), to mediate many important cellular functions, including cell proliferation (Zhang et al., 2001), migration (Davy and Robbins, 2000), adhesion (Davy et al., 1999; Davy and Robbins, 2000), and repulsion (Holmberg et al., 2000). Human Eph receptors are divided into two subclasses, EphAs (nine members; A1-8, A10) and EphBs (five members; B1-4, B6), based on their sequence similarity and ligand affinity (Pasquale, 2004; 2005; Himanen et al., 2007; Noberini et al., 2012; Lisabeth et al., 2013; Darling and Lamb, 2019). The extracellular region of Eph receptors consists of an ephrin-binding domain, a cysteine-rich EGF-like motif, and 2 fibronectin repeats (type III). The intracellular region of Eph receptors is made up of a tyrosine kinase domain, sterile alpha motif (SAM), and a PDZ-binding motif; the extracellular and intracellular domains are connected through a transmembrane section (Figure 1A) (Davis et al., 2008; Darling and Lamb, 2019).
The ligands are categorized into two groups based on their structural differences. Ephrin-As (five members; A1-5) are anchored via a glycosylphosphatidylinositol (GPI) moiety to the membrane, while ephrin-Bs (three members; B1-3) traverse the cell membrane and have a short cytoplasmic extension (Figure 1A) (Kullander and Klein, 2002; Pasquale, 2004, 2005; Darling and Lamb, 2019).

Due to the membrane-bound nature of these receptors and ligands, cell-cell contact and binding between Ephs and ephrins are required to initiate intracellular signals for canonical ligandmediated signaling, in which dimerization of the Eph receptors is regulated by the clustering of ligand complexes (Poliakov et al., 2004; Liang et al., 2019). Interactions between Eph receptors and ephrin ligands influence several physiological processes during development and aging, like axon guidance (Pasquale et al., 1992; Henkemeyer et al., 1994), tissue patterning (Xu et al., 1995), angiogenesis in developing embryos (Wang et al., 1998), bone homeostasis (Zhao et al., 2006), insulin production (Konstantinova et al., 2007), immune surveillance (Luo et al., 2011; Darling and Lamb, 2019), retinal cell patterning (Frisen et al., 1998; Marler et al., 2008), cochlear development (Defourny, 2019), actin cytoskeleton regulation (Carter et al., 2002; Yang et al., 2006; Cheng et al., 2013), cellular adhesion through intercellular junctions (Jorgensen et al., 2009), and cell migration (Matsuoka et al., 2005; Pasquale, 2008). EphA and 
EphB receptors mainly interact and bind to ephrin-As and ephrin-Bs, respectively (Takemoto et al., 2002; Himanen et al., 2004), and each receptor can interact with multiple ligands, and vice versa (Gale et al., 1996). Cross interactions between EphAs and ephrin-Bs or EphBs and ephrin-As can also occur, though those interactions are relatively less common (Gale et al., 1996; Kullander and Klein, 2002). Upon receptor-ligand binding, the signaling pathway acts bidirectionally to initiate forward signaling through receptor kinase activity and reverse signaling in the ligand-bearing cell (Liang et al., 2019). Forward signaling in Ephs involves phosphorylation of tyrosines in a juxtamembrane location located $\mathrm{N}$-terminal to the tryosine kinase domain and within the activation loop of the tyrosine kinase domain (Wiesner et al., 2006; Fang et al., 2008; Balasubramaniam et al., 2011; Taylor et al., 2017; Liang et al., 2019). Reverse signaling in ephrin-As usually requires recruitment of other kinases to the cell membrane (e.g. Fyn, a member of the Src kinase family), and activation of ephrin-Bs occurs through the phosphorylation of the tyrosinses in the cytoplasmic tail by Src family kinases (Pasquale, 2008; Lisabeth et al., 2013; Taylor et al., 2017; Wu et al., 2019). Although ephrin-As do not have a cytoplasmic tail, they can still activate intracellular signals, in cis, within the cell and in trans, on neighboring cells (Lisabeth et al., 2013). Noncanonical signaling that is independent of ligand or receptor binding can also occur. Ephrin-independent non-canonical EphA2 signaling is a hallmark of cancers where the receptor is upregulated, accompanied by low expression of ephrin-As or dysfunction of forward signaling in ephrin-A-bearing cells (Gopal et al., 2011; Stahl et al., 2011; Lisabeth et al., 2013). Non-canonical ligand-independent EphA2 signaling depends on phosphorylation of S897 in linker segment connecting the tyrosine kinase and SAM domains by Akt, Rsk, or PKA, leading to increased cell invasion (Miao et al., 2009; Zhou et al., 2015; Barquilla et al., 2016). The ephrin-B1 ligand can induce a cellular response by transducing signals independently, without being activated by any Eph receptors, through phosphorylation by fibroblast growth factor receptors (FGFR) (Lee et al., 2009).

Eph-ephrin signaling initates widespread signal cascades during development, growth, and disease in various tissues and organ systems through cell-cell interactions. These signaling pathways have been reviewed in detail previously (Pasquale, 2008), and we provide a brief overview here (Figure 1B). Crosstalk between integrins and Eph-ephrin signaling results in cell-cell adhesion (Davy and Robbins, 2000; Gu and Park, 2001). These two pathways meet at the level of cytoplasmic kinases including PI3K, MAPK or small GTPases, such as Rho, Rac or Ras (Figure 1B) (Arvanitis and Davy, 2008). E-cadherin can play a direct role by inhibiting phosphorylation of EphA2 leading to cell adhesion or have an indirect function by stabilizing cell-cell contacts to promote interactions between ephrins and Ephs, including EphB/ ephrin-B binding, to promote adherens junction formation (Zantek et al., 1999; Ireton and Chen, 2005; Noren and Pasquale, 2007). Downstream effectors of Eph-ephrin signaling, like Rac/Rho GTPases, are responsible for the cytoskeletal organization and cell-cell interactions involving cell shape, adhesion, and migration (Lisabeth et al., 2013).
PI3K-Akt/PKB and Ras/MAPK signaling have been reported to be influenced by EphA2 during cell migration and cell proliferation, respectively (Jiang et al., 2015; Liang et al., 2019). Gap junctions and connexins are involved in embryo patterning and organogenesis, and gap junction communication can be inhibited by the Eph-ephrin signaling (Mellitzer et al., 1999; Arvanitis and Davy, 2008). Claudins interact with EphA2 or ephrin-B1 to control intercellular permeabilization and cell adhesion (Arvanitis and Davy, 2008).

\section{Eye Lens Pathology and Eph-ephrin Signaling in Human Lenses}

The eye has two main refractive tissues, the cornea and the lens. Although the cornea contributes $2 / 3$ of the focusing power of the eye, the lens is responsible for the fine focusing component of vision. The lens is a transparent, ellipsoid organ in the anterior chamber that changes shape to focus light from objects that are far or near (Lovicu and Robinson, 2004). During accommodation, the lens becomes more convex to focus light from near objects clearly onto the retina (Figure 2A). With age, the lens loses its accommodative function, resulting in presbyopia and the need for reading glasses (Lovicu and Robinson, 2004; Michael and Bron, 2011). The increasing stiffness of the aging lens has been postulated to be a cause for presbyopia (Heys et al., 2004; Heys et al., 2007; Weeber et al., 2007). In addition to its biomechanical properties, the transparency of the lens is essential to its function. Cataracts are the leading cause of blindness worldwide (World Health Organization, 2019). There are several risk factors associated with cataract formation, such as exposure to UV radiation, the effects of reactive oxygen species, nutritional deficits, and the influence of genetic mutations (Shiels and Hejtmancik, 2017; Sella and Afshari, 2019; Uwineza et al., 2019). However, little is known about the cellular and molecular mechanisms for age-related cataracts. Currently, surgery is the only option to remove cataracts, and there are no treatments to prevent or delay cataracts.

Recent reports have linked dysfunction of Eph-ephrin signaling to congenital and age-related cataracts in human patients. Mutations in the EPHA2 gene can cause a variety of congenital (Zhang et al., 2009; Kaul et al., 2010; Park et al., 2012; Dave et al., 2013; Li et al., 2016; Berry et al., 2018; Zhai et al., 2019) and age-related (Jun et al., 2009; Tan et al., 2011; Sundaresan et al., 2012; Lin et al., 2014) cataracts (Table 1). Non-synonymous single nucleotide polymorphisms (nsSNPs) in the EFNA5 gene, which encodes the ephrin-A5 protein, have also been reported to cause age-related cataracts in humans (Table 1) (Lin et al., 2014). nsSNPs are missense or nonsense mutations resulting from the substitution of a single nucleotide leading to one amino acid change in a protein sequence that could potentially, but not necessarily, affect the protein structure, folding, interactions, and/or functions (Yates and Sternberg, 2013; Zaharan et al., 2018). In addition to nsSNPs in the coding region of genes, there are also non-coding SNP. SNP rs6603883, which is in the promoter region of EPHA2 within the PAX2-binding motif, 

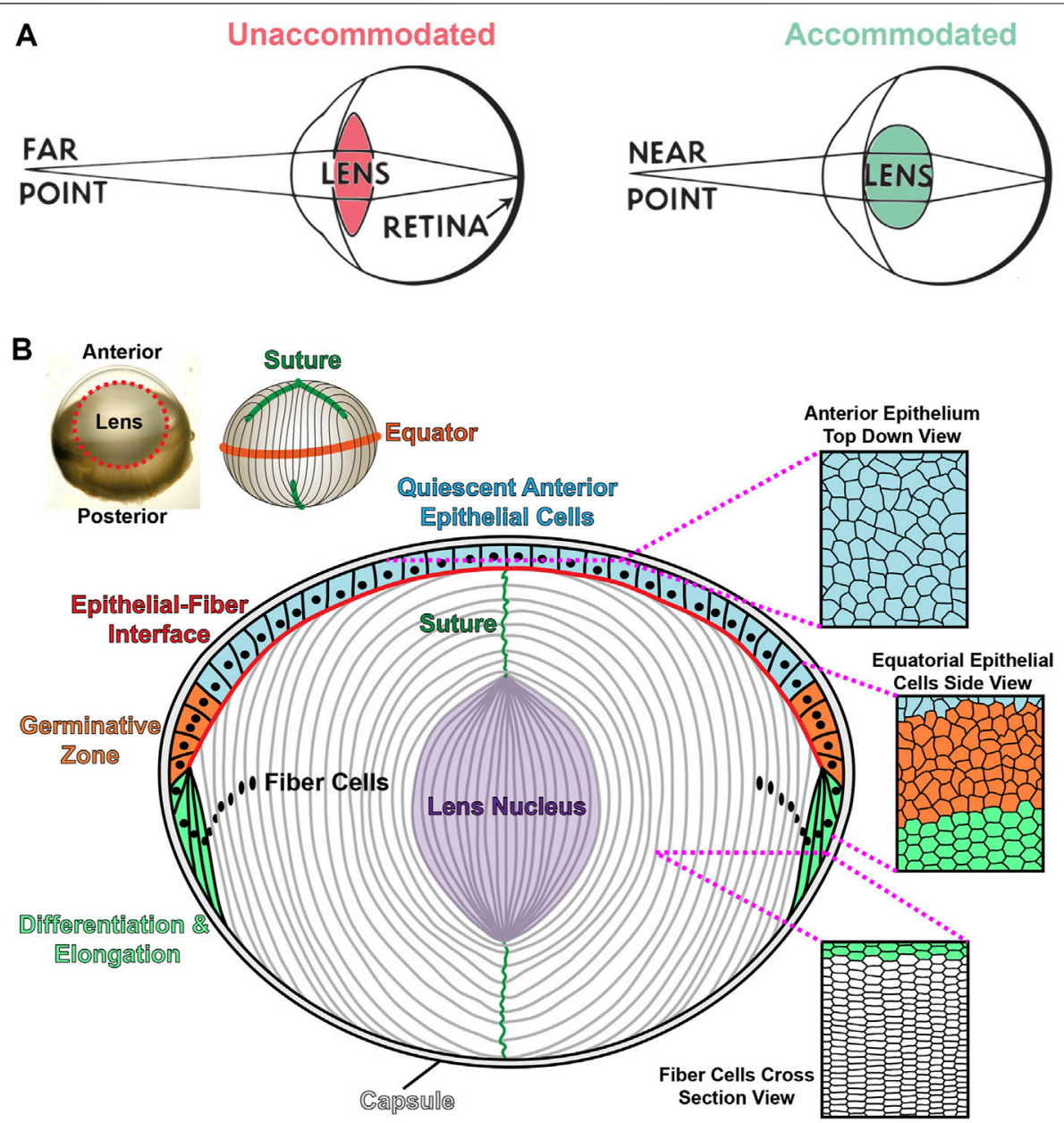

FIGURE 2 | Lens accommodation and anatomy. (A) The lens changes shape to fine focus light coming from sources at various distances onto the retina. When viewing objects that are far away, the lens is unaccommodated and relatively flat (left). During accommodation, the lens becomes more spherical to focus near objects (right). Adapted from an open-source Pearson Scott Foster illustration (not drawn to scale). (B) An illustration (not drawn to scale) depicting a longitudinal (anteriorposterior) section of the lens with a monolayer of epithelial cells on the anterior hemisphere (colored cells) and a bulk mass of elongated lens fibers (white cells). Lens fibers extend from the anterior to posterior poles. The lens capsule, a thin basement membrane, encapsulates the entire tissue. Anterior epithelial cells (blue) are cobblestone in shape and quiescent. These cells normally do not proliferate. Equatorial epithelial cells (orange) in the germinative zone proliferate, migrate and differentiate into new layers of lens fibers. During migration and differentiation, equatorial epithelial cells transform from randomly organized cells (orange) into highly organized hexagonal cells arranged into neat rows (green). Lifelong lens growth depends on the addition of new fiber cells in concentric shells at the periphery of the lens. Lens fibers retain the organized hexagonal rows as seen in the cross-section view. Newly formed fibers elongate toward the anterior and posterior poles, migrating along the apical surface of epithelial cells or the posterior capsule, respectively. Fully elongated fibers at the anterior and posterior poles will detach from the epithelial cells or lens capsule and contact the elongating fiber from the opposing sides forming the Y-suture. Fiber cell maturation eliminates light-scattering cell organelles in the inner fiber cells, and the lens nucleus, or the central core of the tissue, is composed of tightly compacted fiber cells in the middle of the lens (purple). Modified from (Cheng et al., 2019).

has been reported to affect EphA2 protein levels. This downregulation of EphA2 levels alters the downstream MAPK/AKT pathway and affects other extracellular matrix (ECM) and cytoskeletal genes to cause cataracts (Ma et al., 2017). Studies of EPHA2 and EFNA5 mutations have been carried out in diverse populations, including American, Indian, Pakistani, Chinese, British, and Australian families (Shiels et al., 2008; Zhang et al., 2009; Sundaresan et al., 2012). The most common EPHA2 mutations occur in the tyrosine kinase domain, which affects adherens junctions (Jun et al., 2009; Kaul et al., 2010; Patel et al., 2017; Zhai et al., 2019), or in the SAM domain, which results in structural disruption of the EphA2 receptor (Shiels et al., 2008; Zhang et al., 2009; Dave et al., 2013; Shentu et al., 2013). Several nsSNPs in EPHA2 affect the stability and translational regulation of the protein (Lin et al., 2014; Li et al., 2016; Li et al., 2021) and have been associated with congenital and age-related cataracts in humans (Jun et al., 2009; Kaul et al., 2010; Dave et al., 2013; Zhai et al., 2019; Li et al., 2021). The mechanisms for cataractogenesis in human patients with these mutations remain unclear and require further study. Hence, several groups are working on knockout or mutant mouse models 
TABLE 1 | EPHA2 and EFNA5 cataract-causing mutations in humans.

\section{EPHA2 mutation (location)}

Juxtamembrane domain mutation (p.Pro548Leu); SAM domain variants (p.Asp942fs + Cys71); (p.Ala959Thr)

Mutation in the tyrosine kinase domain (p.Gly668Asp)

\begin{tabular}{ll}
\hline Kinase domain mutation (p.Gln669His) & $\begin{array}{l}\text { Saudi Arabian family } \\
- \text { AD }\end{array}$ \\
\hline Kinase domain mutation (p.Ala785Thr) & Pakistani family - AR \\
\hline SAM domain mutation (p.Arg890Cys) & Chinese family - AD \\
\hline $\begin{array}{l}\text { SAM domain mutations (p.Thr940lle); } \\
\text { (p.Val972GlyfsX39); (c.2826-9G>A) }\end{array}$ & Chinese, British, and \\
\hline
\end{tabular}

SAM domain mutation (p.Gly948Trp)

Synonymous mutation (p.Lys935); Nonsynonymous mutation (p.Glu934Lys)

Recurrent splice-site mutation c.2826-9G>A British family - AD in EPHA2 gene

Intergenic variant ( $r$ 477558 $\mathrm{G}>\mathrm{A}$ ) and regulatory region variant (rs7548209 $\mathrm{G}>\mathrm{C}$ )

Intergenic variant (rs477558 G>A) and regulatory region variant ( $r 57548209 \mathrm{G}>\mathrm{C}$ ), Intron variant ( $r s 3768293 \mathrm{G}>\mathrm{A}, \mathrm{C}, \mathrm{T})$

\begin{tabular}{|c|c|c|c|c|}
\hline Non-synonymous SNP (rs137853199 C>A) & Han Chinese & Age-related cortical cataracts & $\begin{array}{l}\text { Altered protein stability and degradation, } \\
\text { and cell mobility }\end{array}$ & Li et al. (2021) \\
\hline Non-synonymous SNPs (rs2291806 C>T) & SNP database & Age-related cataracts & Not known & $\begin{array}{l}\text { (Masoodi et al., } \\
\text { 2012) }\end{array}$ \\
\hline 3' EphA2 SNP (rs7543472 C>T) & Indians & $\begin{array}{l}\text { Age-related posterior sub- } \\
\text { capsular cataracts }\end{array}$ & Not known & $\begin{array}{l}\text { Sundaresan } \\
\text { et al. (2012) }\end{array}$ \\
\hline 3' EphA2 SNP (rs7543472 C>T) & Indians & $\begin{array}{l}\text { Age-related cataracts (nuclear, } \\
\text { cortical, posterior-sub- } \\
\text { capsular and mixed cataract) }\end{array}$ & Not known & $\begin{array}{l}\text { (Aslam et al., } \\
\text { 2020) }\end{array}$ \\
\hline $\begin{array}{l}\text { Tyrosine kinase domain mutation } \\
\text { (c.Arg721Gln); Regulatory region mutation } \\
\text { (rs7548209 G>C); Synonymous mutation } \\
\text { (rs6678616 C>G/T) }\end{array}$ & Caucasians & Age-related cortical cataracts & $\begin{array}{l}\text { Impaired adherens junction and cellular } \\
\text { stress }\end{array}$ & Jun et al. (2009) \\
\hline Synonymous polymorphism rs3754334 & $\begin{array}{l}\text { Meta-analysis (Indian, } \\
\text { Chinese and American } \\
\text { populations) }\end{array}$ & Age-related cataracts & $\begin{array}{l}\text { Changes in the EPHA2 protein } \\
\text { configuration }\end{array}$ & $\begin{array}{l}\text { (Yang et al., } \\
\text { 2013) }\end{array}$ \\
\hline $\begin{array}{l}\text { Functional non-coding SNP rs6603883 in the } \\
\text { promoter region }\end{array}$ & $\begin{array}{l}\text { Americans (Cystinosis } \\
\text { samples) }\end{array}$ & Age-related cataracts & $\begin{array}{l}\text { Alterations in the MAPK/ AKT signaling } \\
\text { pathways, extracellular matrix and } \\
\text { cytoskeletal genes }\end{array}$ & Ma et al. (2017) \\
\hline
\end{tabular}

EFNA5 mutation (Location)

Non-Synonymous SNPs (c.668C>T p.Ala223Val), (c.-27C>G), Synonymous SNP \begin{tabular}{lc} 
Population & Phenotype \\
\hline Chinese & Age-related cataracts
\end{tabular} (c.102C>T)

\section{Potential cause}

References
South-Eastern

Australians - AD

Han Chinese family - AD Congenital posterior subcapsular cataract
Nuclear, total, subcapsular,

Affected phosphorylation profile of tyrosine residues
Dave et al.

(2013)

Destabilization of EphA2, change in amino Zhai et al. acid polarity, change in subcellular (2019) localization

Nuclear, posterior subcapsular Not known infantile cataract

Autosomal recessive congenital cataracts

Progressive congenital posterior sub-capsular cataract

Congenital posterior polar cataract

Patel et al.

(2017)

Kaul et al. (2010) (2013) (2009)

American family - AD
Han Chinese - Sporadic
British family - AD

Han Chinese

Han Chinese Congenital posterior
subcapsular cataract

Sporadic congenital cataracts (total/cortical cataract)

\section{Congenital posterior nuclear} cataracts

Age-related cortical cataracts

Deleterious effect on the protein structure, effect on adherens junction

Structural alteration of EphA2 protein

Defective oligomerization interface, Loss of function due to binding with Low molecular weight protein tyrosine phosphatase (LMW-PTP)
EphA2 recept

Shentu et al.

Zhang et al.

Shiels et al. (2008)

Not known Li et al. (2016)

Not known Berry et al.

(2018)

Tan et al. (2011)

(Huang et al. 2019)

Age-related cataracts Not known

Not known

(Huang et al.,
2019)



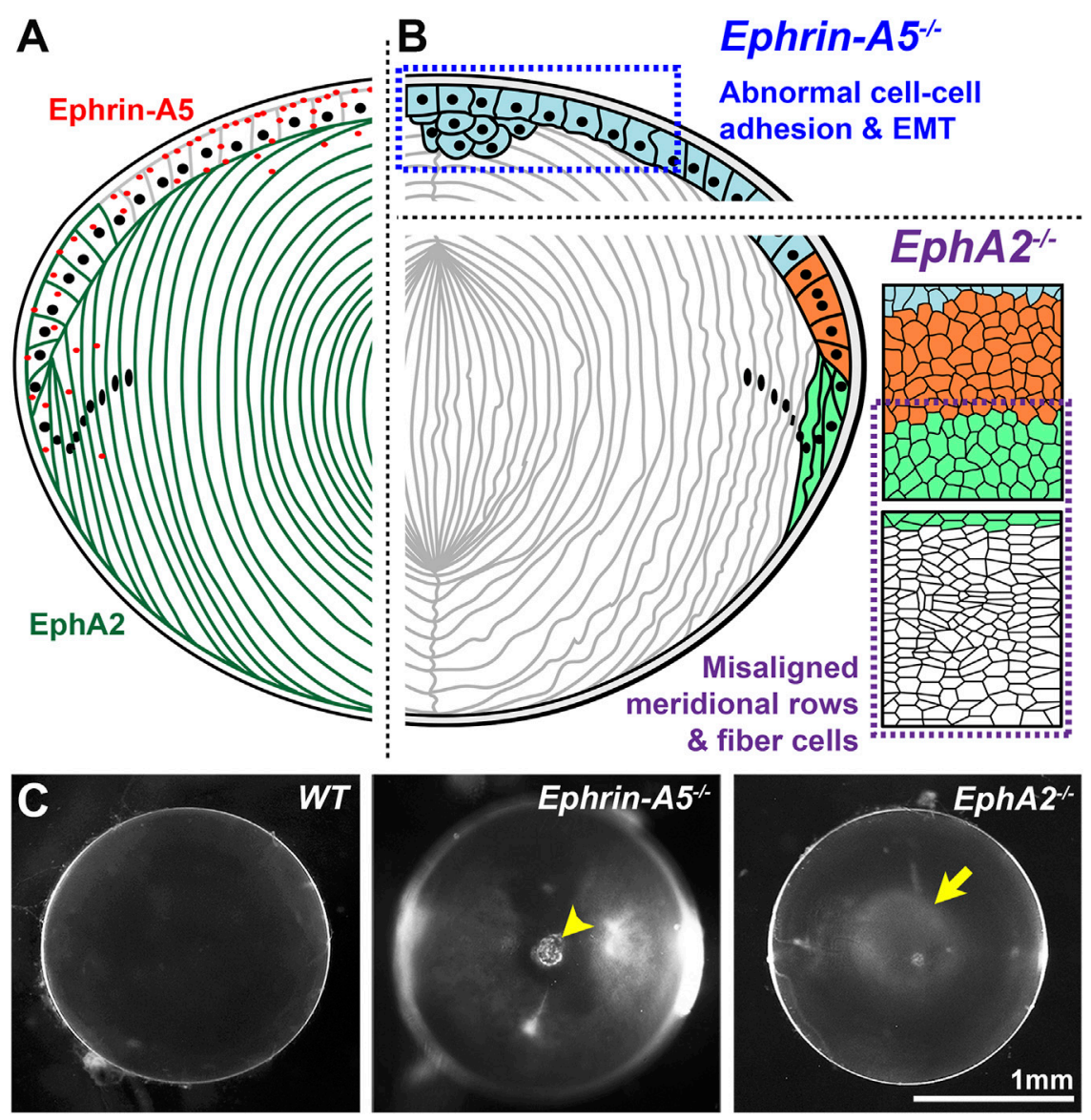

FIGURE 3 | EphA2 and ephrin-A5 in mouse lenses. (A) EphA2 (green) is mainly expressed in equatorial epithelial cells and lens fiber cells, while ephrin-A5 (red) is mainly present in anterior epithelial cells with some expression in peripheral fiber cells and in fiber cell tips near the lens suture. (B) In C57BL/6J genetic background mice, loss of ephrin-A5 leads to abnormal cell-cell adhesion between anterior epithelial cells and epithelial-to-mesenchymal transition (EMT) of these normally quiescent cells. In contrast, disruption of EphA2 in C57BL/6J mice leads to disorder of the equatorial epithelial cells, which leads to abnormal lens fiber cell shape. (C) The normal wild-

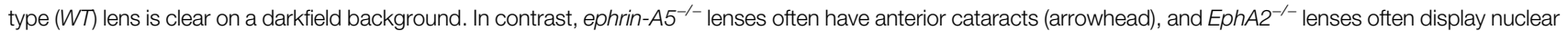
cataracts at the center of the lens (arrow). These images are of lenses from three-week-old mice in the C57BL/6J genetic background. Modified from (Cheng et al., 2017). Illustrations are not drawn to scale. Scale bar, $1 \mathrm{~mm}$.

to dissect the roles of Eph-ephrin signaling in cataractogenesis and lens homeostasis.

\section{Roles of Ephrin-A5 in Maintaining Anterior Epithelial Cells and Fiber Cells}

The lens, derived from the surface ectoderm (McAvoy, 1978a; McAvoy, 1978b), is an ellipsoidal mass of cells composed of a monolayer of epithelial cells covering the anterior hemisphere and many layers of concentrically organized fiber cells extending from the anterior to posterior poles (Figure 2B) (Lovicu and Robinson, 2004). The entire lens is encapsulated by a basement membrane, known as the lens capsule (Lovicu and Robinson, 2004). The anterior epithelial cells are normally mitotically inactive while epithelial cells in the germinative zone of the equatorial region undergo continuous proliferation, migration, differentiation, and elongation to form new generations of lens fiber cells (Figure 2B) (Piatigorsky, 1981; Kuszak et al., 2004a;
Kuszak et al., 2006). Direct immunofluorescence studies showed that the ephrin-A5 protein is detected in anterior epithelial cells, anterior tips of fiber cells and peripheral equatorial fibers in mouse lenses (Figure 3A) (Cheng and Gong, 2011; Cheng et al., 2017; Zhou and Shiels, 2018). Indirect immunofluorescence, using EphA5-alkaline phosphatase affinity probe for ephrin ligand detection, showed a similar epithelial and peripheral fiber staining pattern for ephrin-A5 in the lens (Son et al., 2013).

The lens phenotype for ephrin-A5 knockout $\left({ }^{-/-}\right.$or $\left.\mathrm{KO}\right)$ mice varies greatly depending on genetic background (Table 2) (Cooper et al., 2008; Cheng and Gong, 2011; Son et al., 2013;

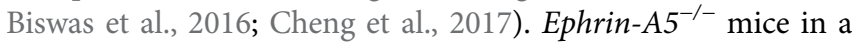
mixed genetic (129/Sv:C57BL/6) background have severe and nearly whole cataracts at 6 months of age with posterior capsule rupture, and lenses from younger mice have many cellular abnormalities, including vacuoles and alterations in the fiber cell shape, size, organization, and packing (Cooper et al., 2008; Son et al., 2013; Biswas et al., 2016; Zhou and 
TABLE 2 | EphA2 and ephrin-A5 knockouts and mutations in mice.

\begin{tabular}{|c|c|c|c|c|c|}
\hline $\begin{array}{l}E p h A 2^{-/-} \\
\text {genetic } \\
\text { background }\end{array}$ & $\begin{array}{l}\text { Knock-out/-in } \\
\text { strategy }\end{array}$ & Phenotype (age) & Cellular changes & $\begin{array}{l}\text { Potential cause } \\
\text { for cataracts }\end{array}$ & References \\
\hline $\begin{array}{l}\text { 129/SVJ: } \\
\text { C57BL/6J }\end{array}$ & $\begin{array}{l}\text { Secretory gene } \\
\text { trapping (intron 1) }\end{array}$ & $\begin{array}{l}\text { Cortical cataracts progressing } \\
\text { to involve the whole lens and } \\
\text { lens rupture (not provided) }\end{array}$ & & & Jun et al. (2009) \\
\hline FVB/NJ & $\begin{array}{l}\text { Secretory gene } \\
\text { trapping (between } \\
\text { exon } 5 \text { and } \\
\text { intron 6) }\end{array}$ & $\begin{array}{l}\text { Cortical cataracts ( } 3 \text { months) } \\
\text { progressing to involve the } \\
\text { whole lens ( } 6 \text { months) and } \\
\text { finally lens rupture ( } 8 \text { months) }\end{array}$ & $\begin{array}{l}\text { Clusters of cortical vacuoles } \\
\text { (1 month), upregulation of Hsp25 } \\
\text { protein }\end{array}$ & $\begin{array}{l}\text { Cellular stress and protein } \\
\text { misfolding }\end{array}$ & Jun et al. (2009) \\
\hline $\begin{array}{l}\text { Mixed FVB: } \\
\text { C57BL6J }\end{array}$ & $\begin{array}{l}\text { Secretory gene } \\
\text { trapping (between } \\
\text { exon } 5 \text { and } \\
\text { intron 6) }\end{array}$ & $\begin{array}{l}\text { Mild anterior cortical lens } \\
\text { opacity ( } 11 \text { weeks); severe } \\
\text { anterior cortical opacities } \\
\text { (18 weeks) }\end{array}$ & & & Dave et al. (2021) \\
\hline C57BL/6J & $\begin{array}{l}\text { Secretory gene } \\
\text { trapping (between } \\
\text { exon } 5 \text { and } \\
\text { intron 6) }\end{array}$ & $\begin{array}{l}\text { Mild anterior cortical lens } \\
\text { opacity ( } 11 \text { weeks); severe } \\
\text { anterior cortical opacities } \\
\text { (38 weeks) }\end{array}$ & $\begin{array}{l}\text { Disorganized, irregularly shaped } \\
\text { and swollen fiber cell and lens } \\
\text { epithelium have vacuoles }\end{array}$ & Fiber cell disorganization & Dave et al. (2021) \\
\hline C57BL/6J & $\begin{array}{l}\text { Insertion of vector } \\
\text { in exon } 5\end{array}$ & $\begin{array}{l}\text { Mild nuclear cataract (P21), } \\
\text { disrupted gradient refractive } \\
\text { index ( } 8 \text { weeks) and increased } \\
\text { resilience ( } 8 \text { weeks) }\end{array}$ & $\begin{array}{l}\text { Misaligned meridional equatorial } \\
\text { epithelial cells and lens fulcrum, } \\
\text { disorganized fiber cells, disrupted } \\
\text { suture apex centration and } \\
\text { abnormal fiber cell membrane } \\
\text { conductance }\end{array}$ & $\begin{array}{l}\text { Abnormal nuclear fiber } \\
\text { morphology and } \\
\text { compaction }\end{array}$ & $\begin{array}{l}\text { Cheng and Gong (2011), Cheng } \\
\text { et al. (2013), Cheng et al. (2017), } \\
\text { Cheng (2021), Cheng et al. } \\
\text { (2021), Cheng et al. (2022) }\end{array}$ \\
\hline C57BL/6J & $\begin{array}{l}\text { Insertion of vector } \\
\text { in exon } 5\end{array}$ & $\begin{array}{l}\text { Smaller spherical lenses }(2+ \\
\text { weeks) with reduced refractive } \\
\text { power of the outer lens layers }\end{array}$ & $\begin{array}{l}\text { Disorganized fiber cells, } \\
\text { disturbed lens gradient index, } \\
\text { and suture misalignment }\end{array}$ & $\begin{array}{l}\text { Disrupted migration of fiber } \\
\text { cells }\end{array}$ & Shi et al. (2012) \\
\hline C57BL/6J & $\begin{array}{l}\text { Insertion of vector } \\
\text { in exon } 5\end{array}$ & $\begin{array}{l}\text { Small lens with degraded } \\
\text { optical quality (P21) }\end{array}$ & $\begin{array}{l}\text { Decreased proliferation of lens } \\
\text { epithelial cells, misaligned fiber } \\
\text { cells with disturbed suture } \\
\text { formation }\end{array}$ & $\begin{array}{l}\text { Defective early patterning in } \\
\text { cell differentiation } \\
\text { contribute to later defects in } \\
\text { patterning }\end{array}$ & Zhou and Shiels, (2018) \\
\hline
\end{tabular}

\begin{tabular}{|c|c|c|c|c|c|}
\hline $\begin{array}{l}\text { Ephrin-A5 mutant } \\
\text { genetic background }\end{array}$ & $\begin{array}{l}\text { Knock-out/-in } \\
\text { strategy }\end{array}$ & Phenotype (Age) & Cellular changes & Potential cause for cataracts & References \\
\hline $\begin{array}{l}\text { EphA2-R722Q } \\
\text { C57BL/6J }\end{array}$ & $\begin{array}{l}\text { CRISPR/Cas9 } \\
\text { gene editing }\end{array}$ & $\begin{array}{l}\text { No obvious cataracts } \\
\text { (P21-12 months) }\end{array}$ & $\begin{array}{l}\text { Longer/unequal posterior suture } \\
\text { branches at P30 }\end{array}$ & $\begin{array}{l}\text { Patterning defects due to the disruption } \\
\text { of cytoskeleton-associated protein } \\
\text { expression }\end{array}$ & $\begin{array}{l}\text { Zhou et al. } \\
(2021)\end{array}$ \\
\hline $\begin{array}{l}\text { EphA2-del722 } \\
\text { C57BL/6J }\end{array}$ & $\begin{array}{l}\text { CRISPR/Cas9 } \\
\text { gene editing }\end{array}$ & $\begin{array}{l}\text { Translucent regions } \\
\text { (P21-12 months) }\end{array}$ & $\begin{array}{l}\text { Disrupted meridional epithelial-to-fiber } \\
\text { cell alignment at the equator, deviated } \\
\text { polar axis at the posterior pole with } \\
\text { severe suture defects, misaligned } \\
\text { hexagonal fiber cell radial columns, and } \\
\text { retention of EphA2 in the cytoplasm }\end{array}$ & $\begin{array}{l}\text { Patterning defects in the epithelial and } \\
\text { fiber cells and disruption of } \\
\text { cytoskeleton-associated protein } \\
\text { expression }\end{array}$ & $\begin{array}{l}\text { Zhou et al. } \\
(2021)\end{array}$ \\
\hline
\end{tabular}

\begin{tabular}{|c|c|c|c|c|c|}
\hline $\begin{array}{l}\text { Ephrin-A5 } \\
\text { genetic background }\end{array}$ & $\begin{array}{l}\text { Knockout } \\
\text { strategy }\end{array}$ & Phenotype (Age) & Cellular changes & $\begin{array}{l}\text { Potential cause for } \\
\text { cataracts }\end{array}$ & References \\
\hline $\begin{array}{l}\text { Mixed 129/Sv: } \\
\text { C57BL/6 }\end{array}$ & $\begin{array}{l}\text { Insertion of } \\
\text { vector in exon }\end{array}$ & $\begin{array}{l}\text { Progressive cortical cataracts } \\
\text { with rupture of the posterior } \\
\text { lens capsule ( } 2 \text { months) }\end{array}$ & $\begin{array}{l}\text { Disorganized and rounded fiber } \\
\text { cells }\end{array}$ & $\begin{array}{l}\text { Loss of cell-cell adhesion } \\
\text { due to loss of } \mathrm{N} \text {-cadherin } \\
\text { from the cytoplasmic } \\
\text { membrane }\end{array}$ & Cooper et al. (2008) \\
\hline $\begin{array}{l}\text { Mixed 129/Sv: } \\
\text { C57BL/6 }\end{array}$ & $\begin{array}{l}\text { Insertion of } \\
\text { vector in exon }\end{array}$ & Nuclear cataract (P21) & $\begin{array}{l}\text { Presence of large vacuoles in the } \\
\text { equatorial region, severe fiber } \\
\text { cell degeneration, and lens } \\
\text { rupture }\end{array}$ & $\begin{array}{l}\text { Affected fiber cell packing } \\
\text { during epithelial cell } \\
\text { differentiation }\end{array}$ & Son et al. (2013) \\
\hline
\end{tabular}


TABLE 2 | (Continued) EphA2 and ephrin-A5 knockouts and mutations in mice.

\begin{tabular}{|c|c|c|c|c|c|c|c|}
\hline $\begin{array}{l}\text { Ephrin-A5 } \\
\text { genetic background }\end{array}$ & $\begin{array}{l}\text { Knockout } \\
\text { strategy }\end{array}$ & Phenotype (Age) & Cellular changes & \multicolumn{2}{|c|}{$\begin{array}{c}\text { Potential cause for } \\
\text { cataracts }\end{array}$} & \multicolumn{2}{|c|}{ References } \\
\hline $\begin{array}{l}\text { Mixed 129/Sv: } \\
\text { C57BL/6 }\end{array}$ & $\begin{array}{ll}\text { Insertion of } & \mathrm{N} \\
\text { vector in exon } & \mathrm{fc} \\
& \mathrm{rl}\end{array}$ & $\begin{array}{l}\text { Nuclear cataracts ( } 2 \text { months) } \\
\text { followed by posterior capsule } \\
\text { rupture }\end{array}$ & $\begin{array}{l}\text { Disruption of } \mathrm{N} \text {-cadherin- } \beta \text { - } \\
\text { catenin complex that affects the } \\
\text { interlocking protrusions causing } \\
\text { cataract }\end{array}$ & \multicolumn{2}{|c|}{$\begin{array}{l}\text { Presence of membranous } \\
\text { globules along the fiber cells } \\
\text { disrupted interlocking } \\
\text { protrusions in fiber cells }\end{array}$} & \multicolumn{2}{|c|}{ Biswas et al. (2016) } \\
\hline C57BL/6J & $\begin{array}{ll}\text { Insertion of } & A \\
\text { vector in exon } & m \\
& r \in \\
& \text { in }\end{array}$ & $\begin{array}{l}\text { Anterior polar cataracts (P21), } \\
\text { mild decrease in maximum } \\
\text { refractive index ( } 8 \text { weeks) and } \\
\text { increased resilience ( } 8 \text { weeks) }\end{array}$ & $\begin{array}{l}\text { Disruption of cell-cell adhesion } \\
\text { (E-cadherin and } \beta \text {-catenin) in } \\
\text { anterior epithelial cells leading to } \\
\text { abnormal proliferation, } \\
\text { disorganized suture apex } \\
\text { centration and abnormal fiber } \\
\text { cell membrane conductance }\end{array}$ & \multicolumn{2}{|c|}{$\begin{array}{l}\text { Aberrant EMT in anterior } \\
\text { epithelial cells invading } \\
\text { underlying fiber cells }\end{array}$} & \multicolumn{2}{|c|}{$\begin{array}{l}\text { Cheng and Gong (2011), } \\
\text { Cheng et al. (2017), Cheng } \\
\text { (2021), Cheng et al. (2021), } \\
\text { Cheng et al. (2022) }\end{array}$} \\
\hline C57BL/6J & $\begin{array}{ll}\text { Insertion of } & \mathrm{S} \\
\text { vector in exon } & \mathrm{O}\end{array}$ & $\begin{array}{l}\text { Small lens with degraded } \\
\text { optical quality (P21) }\end{array}$ & $\begin{array}{l}\text { Disturbed epithelial meridional } \\
\text { pattern, radial fiber cell pattern, } \\
\text { and suture disorganization }\end{array}$ & \multicolumn{2}{|c|}{$\begin{array}{l}\text { Defective early patterning in } \\
\text { cell differentiation } \\
\text { contributes to later defects in } \\
\text { patterning }\end{array}$} & \multicolumn{2}{|c|}{ Zhou and Shiels, (2018) } \\
\hline $\begin{array}{l}\text { EphA2-/- ephrin-A5 } \\
\text { double knockout } \\
\text { genetic background }\end{array}$ & $\begin{array}{l}\text { Knockout } \\
\text { strategy }\end{array}$ & Phenotype (Age) & Cellular cha & nges & \multicolumn{2}{|c|}{$\begin{array}{c}\text { Potential cause for } \\
\text { cataracts }\end{array}$} & References \\
\hline C57BL/6J & $\begin{array}{l}\text { Insertion of } \\
\text { vector in exon }\end{array}$ & $\begin{array}{l}\text { Mild nuclear cataract (P21) and } \\
\text { anterior polar cataract (P21) } \\
\text { (additive phenotype from each } \\
\text { single knockout) }\end{array}$ & \multicolumn{2}{|c|}{$\begin{array}{l}\text { Misaligned meridional equatorial } \\
\text { epithelial cells and disorganized fiber } \\
\text { cells and aberrant proliferation of } \\
\text { anterior epithelial cells }\end{array}$} & \multicolumn{2}{|c|}{$\begin{array}{l}\text { Fiber cell disruptions and } \\
\text { aberrant EMT in anterior } \\
\text { epithelial cells }\end{array}$} & $\begin{array}{l}\text { Cheng et al. } \\
(2017)\end{array}$ \\
\hline
\end{tabular}

Shiels, 2018). In C57BL/6J background mice, ephrin- $A 5^{-/-}$lenses displayed anterior polar cataracts caused by abnormal proliferation of anterior epithelial cells undergoing epithelialto-mesenchymal (EMT) transition (Figure 3B) (Cheng and

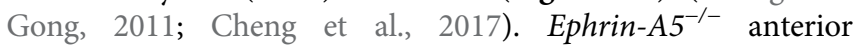
epithelial cells showed punctate, rather than membranelocalized, $\beta$-catenin immunostaining signals along with abnormal E-cadherin staining (Cheng and Gong, 2011). These defects in cell-cell adhesion through adherens junctions likely lead to EMT, and the cluster of abnormal anterior epithelial cells invade the underlying fiber cell layer to cause anterior cataracts in the ephrin-A5 $5^{-1-}$ mice (Figures 3B,C) (Cheng and Gong, 2011). Interestingly, the hexagonal packing of fiber cells in ephrin- $A 5^{-/-}$ lenses in $C 57 B L / 6 J$ background mice appears relatively normal (Cheng and Gong, 2011; Cheng et al., 2017; Cheng et al., 2021). Based on these studies, genetic background strongly influences cataract phenotype and severity in ephrin- $A 5^{-1-}$ mice. While there are anterior epithelial cell defects and cataracts in $C 57 B L / 6 \mathrm{~J}$ background ephrin- $A 5^{-/-}$lenses, severe fiber cell defects are more obvious in mixed (129/Sv:C57BL/6) background $\mathrm{KO}$ mice.

\section{Function of EphA2 in Organizing Equatorial Epithelial Cells and Fiber Cells}

The expression of EphA2 receptor proteins in the lens was identified at equatorial epithelial cell and fiber cell membranes and in fiber cell tips (Figure 3A) (Jun et al., 2009; Cheng and Gong, 2011; Cheng et al., 2017; Zhou and Shiels, 2018). The levels of EphA2 in normal mouse lenses were found to decline with age (Jun et al., 2009). The first report of the lens phenotype in $E p h A 2^{-/-}$mice revealed cortical cataracts that progressed to whole cataracts and lens rupture with age (Table 2) (Jun et al., 2009). These $\mathrm{KO}$ animals were in the $F V B / N J$ genetic background, and EphA2 proteins were sequestered through gene trapping (Mitchell et al., 2001; Guo et al., 2006), leading to the

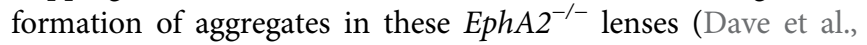
2021). A member of the heat shock protein family, Hsp25, was found to be significantly upregulated in these EphA2 $2^{-/-}$lenses (Jun et al., 2009). The progressive and severe cataracts in these $\mathrm{KO}$ animals were hypothesized to be due to increased cellular stress and misfolding of proteins (Jun et al., 2009). The secretory gene trapping $\mathrm{KO}$ strategy involves the insertion of a secretory trapping vector between exon 5 and intron 6 of the EphA2 gene, resulting in a truncated form of EphA2 without exons 6 through 17 (Mitchell et al., 2001). The partial translated EphA2 ectodomain is bound to a reporter protein, $\beta$-galactosidase, that traps the fusion protein in the cytoplasm and forms aggregates. The aggregates trigger a moderate unfolded-protein response (UPR) (Jun et al., 2009; Dave et al., 2021). A second gene trapping EphA2 $2^{-/-}$mouse line in the mixed 129/Sv J:C57BL/6J genetic background was also examined (Jun et al., 2009). This second gene trap mouse line had insertion of the gene trap in intron 1 resulting in truncated EphA2 protein with exon 1 fused to $\beta$-galactosidase (Naruse-Nakajima et al., 2001). The two gene trapping EphA2 $2^{-/-}$mouse lines have similar cataract phenotypes (Jun et al., 2009). It is not clear whether UPR in these EphA2 ${ }^{-/-}$ lenses directly affects cataract phenotype and severity. 
A recent report showed that when the exon 5/intron 6 genetrapping EphA2 $2^{-1-}$ mice were backcrossed to the C57BL/6J genetic background, the $\mathrm{KO}$ lenses developed progressively more severe cortical cataracts, but the opacity did not progress to whole cataracts or lens rupture (Dave et al., 2021). Thus, it is likely that genetic modifiers in the C57BL/6J background affect cataract severity and phenotype. This notion is supported by previous studies showing that the severity of nuclear cataracts due to gap junction disruption is modulated by the $C 57 \mathrm{BL} / 6 \mathrm{~J}$ genetic background (Gong et al., 1998; Gong et al., 1999). Subsequent studies of another EphA2 $2^{-/}$mouse line, which utilized an exon deletion strategy, in the $C 57 B L / 6 J$ genetic background, revealed mild nuclear cataracts (Figure 3C) in young mice and abnormal refractive properties (Cheng and Gong, 2011; Shi et al., 2012; Cheng et al., 2022). Consistent with data from the gene-trapping $E p h A 2^{-/-}$lenses, there is disorganization of lens fiber cells due to the loss of EphA2 (Figure 3B) (Cheng and Gong, 2011; Shi et al., 2012; Cheng et al., 2013; Cheng et al., 2017; Cheng, 2021; Cheng et al., 2022). The genetic modifier(s) that affect cataract phenotype in the $C 57 B L / 6 \mathrm{~J}$ background have yet to be identified in any $\mathrm{KO}$ mouse line.

Lens fiber cells, hexagonal in cross-section, allow low energy and tight packing conformations to minimize light scattering (Figure 2B) (Bassnett et al., 2011; Cheng et al., 2016). Hexagonal cell shape is initially established in equatorial epithelial cells as these differentiating cells organize into meridional rows (Bassnett et al., 2011). The mechanism for this remarkable morphogenesis relies on EphA2 signaling. EphA2 receptors are present at the cell membrane (Bassnett, 2009; Cheng et al., 2013; Cheng et al., 2017) of equatorial epithelial cells, differentiating and mature lens fibers as well as anterior fiber cell tips (Figure 3A) (Jun et al., 2009; Cheng et al., 2017; Zhou and Shiels, 2018). EphA2 recruits Src kinase to the vertices of hexagonal equatorial epithelial cells. Src is then activated by phosphorylation to recruit and activate cortactin to enrich actin at the cell vertices to establish and maintain hexagon cell shape (Figure 3B) (Cheng et al., 2013). Loss of EphA2 causes equatorial lens epithelial cells to have disrupted cell shape that leads to misaligned meridional rows, which in turn leads to disorganization of lens fiber cells (Cheng et al., 2013). In addition to abnormal cell shape, the characteristic undulating surface morphology and presence of protrusions and interdigitations in fiber cells were also disturbed in $E p h A 2^{-1-}$ mice (Shi et al., 2012; Cheng et al., 2022).

The avascular lens relies on a network of gap junction plaques, water channels, and active transport of sodium ions out of the lens to generate its own microcirculation current to bring in nutrients and remove waste (Mathias et al., 1981; Mathias et al., 1997). The loss of EphA2 alters connexin 50 (Cx50) localization to lens fiber cell membranes, presumably compromising gap junction plaque formation and cell-cell communication (Cheng et al., 2021). Loss of either ephrin-A5 or EphA2 also changes the localization of aquaporin 0 , a protein that makes up water channels between cells (Cheng et al., 2021). Surprisingly, these defects do not affect cell-cell coupling in the lens, but disrupt the normal intracellular voltage and membrane conductance of lens fibers. This is the first evidence that these properties of lens fibers could be modulated and that Eph-ephrin signaling is involved in maintaining the ion homeostasis of fiber cells (Cheng et al., 2021).

In vitro studies have been used to understand the mechanism and effect of EphA2 mutations in cataract formation. In HEK293T and aTN4-1 cells, mutations in the SAM domain of EphA2 were found to induce instability, insolubility and dergradation of mutant proteins via a proteasome-dependent pathway (Park et al., 2012). In addition, transfection experiments using epithelial cell culture systems, such as Madin-Darby canine kidney (MDCK) and human colorectal adenocarcinoma (Caco-2) epithelial cells, revealed that SAM domain mutations of EphA2, namely p.T940I and p.D942fsXC7, affect the intercellular contacts due to destabilization of mutant EphA2 proteins (Dave et al., 2016). These two mutations were previously identified to cause severe total, nuclear or posterior polar congenital cataracts in humans (Zhang et al., 2009; Dave et al., 2013). Thus, changes in the EphA2 protein characteristics and conformation results in cataract formation.

\section{Eph-ephrin Signaling and Lens Biomechanics}

Elongating fiber cell tips migrate along the apical surface of epithelial cells anteriorly and along the capsule posteriorly (Figure 2B). At the anterior and posterior poles, the fiber cell tips detach from the anterior epithelium or posterior capsule, respectively, and contact fiber cells from the opposing directions to form the Y-suture (Kuszak et al., 2004a; Kuszak et al., 2004b; Lovicu and Robinson, 2004). Examination of EphA2 ${ }^{-/-}$and ephrin- $A 5^{-/-}$lenses revealed changes in the formation of Y-sutures at the anterior and posterior poles. In both

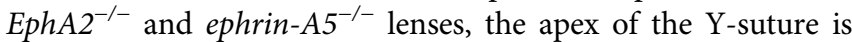
disorganized between concentric fiber cells layers (Cheng, 2021), and these KO lenses more often display additional, abnormal branching of the Y-suture (Zhou and Shiels, 2018; Cheng, 2021), with branching patterns similar to human lenses (Koretz et al., 1994; Kuszak et al., 2004b). Loss of either EphA2 or ephrin-A5 causes mouse lenses to become more spherical, possibly due to the suture patterning defect (Shi et al., 2012; Zhou and Shiels, 2018; Cheng, 2021). Unexpectedly, these suture defects did not

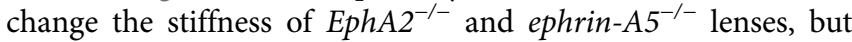
these $\mathrm{KO}$ lenses were more resilient and recovered more fully after compressive load removal (Cheng, 2021). Increased resilience in $\mathrm{KO}$ lenses was due to a change in suture gap area under compression and recovery after load removal (Cheng, 2021). These data indicate that Eph-ephrin signaling influences suture formation, possibly by guiding the migration of lens fiber cell tips toward the anterior and posterior poles and determining the location of the suture apex. The change in resilience due to suture mispatterning suggests that the shape of the Y-suture constrains the elasticity of the lens (Cheng, 2021).

Mice containing an EphA2 mutation (p.R722Q), which is homologus to the human EPHA2 mutation (p.R721Q) associated with age-related cataracts (Jun et al., 2009), were generated using CRISPR/Cas9 technology (Zhou et al., 2021). The generation of mutant EphA2-R722Q mice also resulted in a separate off-target insertion-deletion mutant allele in exon 13 
(EphA2-indel722). EphA2-R722Q mutant lenses (homozygous and heterozygous) were similar in size and transparency to control wild-type lenses, but EphA2-indel722 mutant lenses exhibited translucent regions, disrupted alignment of equatorial hexagonal epithelial and fiber cells, and polar axis shift of the fiber cell tips with severely disrupted suture pattern at the posterior pole (Zhou et al., 2021). There was no significant manifestation of cataract in young (3 weeks old) and old (12 months old) heterozygous and homozygous EphA2-R722Q and EphA2-indel722 mutant mice (Zhou et al., 2021). These results strengthen the hypothesis that EphA2 is required for the precise alignment of fiber cells at the equator and the formation of suture at the posterior pole.

Lifelong lens growth relies on the addition of new layers of lens fiber cells that surround previous generations of cells in concentric shells (Figure 2B). As the fiber cells mature, they are compacted and form a stiff lens nucleus, the center region of the lens (Al-Ghoul et al., 2001; Heys et al., 2004; Lovicu and Robinson, 2004). Recent studies have shown that the compacted lens nucleus is correlated with areas of high refractive index in mouse lenses (Cheng et al., 2019; Cheng et al., 2022). It has long been hypothesized that increased stiffness of the lens nucleus with age increases overall lens stiffness and contributes to the development of presbyopia (Heys et al., 2004; Weeber et al., 2007). We recently examined the morphometric properties of control, EphA $2^{-/-}$, and ephrin- $A 5^{-/-}$lenses. Unexpectedly, we found that $E p h A 2^{-/-}$lenses had smaller and softer lens nuclei, which correlated with decreased gradient refractive index (Cheng et al., 2022). Loss of EphA2 affects mature and perinuclear lens fiber cell morphology leading to abnormal tongue-and-groove interdigitations and loss of normal interlocking protrusions (Cheng et al., 2022). Interestingly, the change in lens nucleus size and stiffness in EphA2 $2^{-/-}$lenses does not affect overall whole lens stiffness (Cheng et al., 2022).

\section{Binding Partners of EphA2 and Ephrin-A5 and Crosstalk With Other Signaling Pathways}

Some tissue and cell culture studies have shown that EphA2 and ephrin-A5 interact with each other to regulate cellular functions, like cell migration (Park et al., 2012), tumorigenicity (Li et al., 2009), and invasive properties of breast cancer (Shaw et al., 2014). Built on these findings, some groups have suggested that EphA2 and ephrin-A5 could be binding partners in the lens (Cooper et al., 2008; Shi et al., 2012; Son et al., 2013). In lens epithelial cells, differences in the epithelial cell phenotype between $E p h A 2^{-/-}$and ephrin- $A 5^{-/-}$lenses suggested that the two proteins function independently of each other. Genetic studies of double $\mathrm{KO}$ EphA $2^{-/-}$ephrin-A5 $5^{-/}$lenses revealed that anterior and equatorial lens epithelial cell phenotypes were additive in the double mutant mice, indicating that EphA2 and ephrin-A5 are not receptor-ligand pair in lens epithelial cells (Cheng et al., 2017). Ephrin-A5 maintains the quiescence of anterior lens epithelial cells, while EphA2 regulates equatorial epithelial cell shape and organization (Cheng and Gong, 2011; Cheng et al., 2013). Studies of lens fiber cell tips and Y-suture formation suggest that loss of EphA2 or ephrin-A5 lead to similar defects in fiber cells at that specific location, indicating possibly that EphA2 and ephrin-A5 interact in this region of the lens (Zhou and Shiels, 2018; Cheng, 2021). This hypothesis is supported by EphA2 and ephrin-A5 immunostaining signals being present at the fiber cell tips near the lens suture (Cheng and Gong, 2011; Cheng et al., 2017). Most cells express a complement of Ephs and ephrins, and thus, in the lens, compensatory mechanisms for the loss of one receptor or ligand could lead to upregulation or downregulation of other receptors and/or ligands in the lens epithelial and fiber cells, which has yet to be investigated.

EphA2 signals through the Src and cortactin pathway to influence actin cytoskeleton in equatorial lens epithelial cells to regulate hexagon cell shape and cell organization (Cheng et al., 2013), similar to interactions previously shown in other tissues between EphA2 and Src (Baldwin et al., 2006; Parri et al., 2007; Faoro et al., 2010). A recent study has confirmed complex formation between EphA2 and Src kinase thereby supporting their direct downstream interaction (Zhou et al., 2021). The development and maintenance of the lens' unique structure are determined by growth factors and signaling pathways (Beebe et al., 1987; Belecky-Adams et al., 1997; Faber et al., 2002; Lovicu and McAvoy, 2005). Fibroblast growth factors (FGF), another group of RTK, have been identified to antagonistically interact with ephrin-B ligands (Pasquale, 2008), resulting in asymmetric cell division and cell fate determination in Ciona embryos (Picco et al., 2007) and in Xenopus eye field formation (Moore et al., 2004). Discs large-1 (Dlg-1), a PDZ protein (Rivera et al., 2009), and FGF (Wang et al., 2010) were found to be involved in lens fiber cell differentiation. Loss of Dlg-1 (Rivera et al., 2009) in mouse lens led to defective fiber cell patterning and cell-cell adhesion. Dlg-1 interacts with EphA2 to influence FGF signaling and regulate lens fiber cells during differentiation and structural maintenance (Lee et al., 2016), suggesting crosstalk between Eph-ephrin signaling, FGF signaling and adherens junctions. In addition, loss of ephrin-A5 caused abnormal association of $\mathrm{N}$-cadherin and $\beta$-catenin in lens fibers of mixed background $\mathrm{KO}$ mice (Cooper et al., 2008) as well as disrupted E-cadherin and $\beta$-catenin staining in anterior epithelial cells of $C 57 B L / 6 J$ background $\mathrm{KO}$ anterior epithelial cells (Cheng and Gong, 2011). These data further indicate the Eph-ephrin signaling is needed for normal cell-cell adhesion and adherens junctions in the lens.

\section{Future Directions and Therapeutic Opportunities}

Eph-ephrin signaling has a wide range of roles during development (e.g., angiogenesis (Salvucci and Tosato, 2012), tissue patterning (Henkemeyer et al., 1994) and neural development (Holmberg et al., 2000)), as well as in the physiology of adult tissues (e.g., insulin secretion (Konstantinova et al., 2007; Jain et al., 2013), bone homeostasis (Zhao et al., 2006)) and in diseases including cancer (Clevers and Batlle, 2006; Guo et al., 2006) and neurological disorders (Fu et al., 2014)). The receptors and 
ligands can play both inhibitor and activator roles through canonical ligand-mediated or non-canonical ligandindependent pathways. From studies using mice to understand the roles of Eph-ephrin signaling in cataractogenesis, the strain background can greatly influence the phenotype and severity and progression of cataracts (Cheng and Gong, 2011; Shi et al., 2012; Cheng et al., 2013; Son et al., 2013; Biswas et al., 2016; Zhou and Shiels, 2018). This has complicated our interpretation of the lens phenotypes and the ability to compare data across different studies. However, the variable cataract phenotypes in mice recapitulate the large variety of human cataracts and suggests the possibility that multiple genetic modifiers modulate cataract severity and progression. Studies to identify genetic modifiers in mice could help unravel cataractogenesis mechanisms in human patients.

While Ephs and ephrins have been studied extensively in other tissues, we are still working toward mapping the spatiotemporal expression patterns of relevant Ephs and ephrins in the lens and determining their direct binding partners and the downstream signaling pathways. In-depth knowledge of the receptors, ligands, their interactions with each other and with other downstream effectors is necessary to understand and formulate therapeutic strategies. Recently, studies have shown the role of Ephs and ephrins in age-related diseases, like Alzheimer's (Cisse et al., 2011) and Parkinson's disease (Jing et al., 2012). Inhibition of specific Ephs can promote the regeneration of damaged neural networks (Fabes et al., 2007; Goldshmit et al., 2011; Spanevello et al., 2013) and control tumor microenvironment (Miao and Wang, 2012; Salvucci and Tosato, 2012), and their activation can

\section{REFERENCES}

Al-Ghoul, K. J., Nordgren, R. K., Kuszak, A. J., Freel, C. D., Costello, M. J., and Kuszak, J. R. (2001). Structural Evidence of Human Nuclear Fiber Compaction as a Function of Ageing and Cataractogenesis. Exp. Eye Res. 72, 199-214. doi:10. 1006/exer.2000.0937

Arvanitis, D., and Davy, A. (2008). Eph/ephrin Signaling: Networks. Genes Dev. 22, 416-429. doi:10.1101/gad.1630408

Aslam, S., Khosa, T., Akbar, A., Latif, M., Chaudhary, M. A., Shaikh, R. S., et al. (2020). Single Nucleotide Polymorphism (rs7543472) in EPHA2 Gene is Associated With Age-Related Cataract in Subjects Enrolled From Multan in Southern Punjab: A Case-Control Study. J. Pak. Med. Assoc. 70, 583-590.

Balasubramaniam, D., Paul, L. N., Homan, K. T., Hall, M. C., and Stauffacher, C. V. (2011). Specificity of HCPTP Variants toward EphA2 Tyrosines by Quantitative Selected Reaction Monitoring. Protein Sci. 20, 1172-1181. doi:10.1002/pro.646

Baldwin, C., Chen, Z. W., Bedirian, A., Yokota, N., Nasr, S. H., Rabb, H., et al. (2006). Upregulation of EphA2 during In Vivo and In Vitro Renal IschemiaReperfusion Injury: Role of Src Kinases. Am. J. Physiology-Renal Physiol. 291, F960-F971. doi:10.1152/ajprenal.00020.2006

Barquilla, A., Lamberto, I., Noberini, R., Heynen-Genel, S., Brill, L. M., and Pasquale, E. B. (2016). Protein Kinase A Can Block EphA2 ReceptorMediated Cell Repulsion by Increasing EphA2 S897 Phosphorylation. MBoC 27, 2757-2770. doi:10.1091/mbc.e16-01-0048

Barquilla, A., and Pasquale, E. B. (2015). Eph Receptors and Ephrins: Therapeutic Opportunities. Annu. Rev. Pharmacol. Toxicol. 55, 465-487. doi:10.1146/ annurev-pharmtox-011112-140226

Bassnett, S. (2009). On the Mechanism of Organelle Degradation in the Vertebrate Lens. Exp. Eye Res. 88, 133-139. doi:10.1016/j.exer.2008.08.017 affect vascular development, cardioprotection and heart tissue maintenance (Stephen et al., 2007; Genet et al., 2012; Goichberg et al., 2013). Recombinant extracellular domains, antibodies, peptides, small molecule agonists and antagonists, antisense oligonucleotides, or siRNAs are some of the therapeutic molecules that can be used to target the Eph-ephrin signaling to either inhibit or activate the signaling pathway to treat various diseases (Barquilla and Pasquale, 2015). We hope that a better understanding of the universe of Ephs and ephrins in the lens and the mechanisms for current therapeutic strategies can be translated to future anti-aging treatment for ocular diseases, like presbyopia and cataracts.

\section{AUTHOR CONTRIBUTIONS}

SM and CC made the figures and wrote the manuscript.

\section{FUNDING}

This work was supported by the National Eye Institute Grant R01 EY032056 to CC.

\section{ACKNOWLEDGMENTS}

We thank Michael Vu for helpful comments and critical reading of this manuscript.

Bassnett, S., Shi, Y., and Vrensen, G. F. J. M. (2011). Biological Glass: Structural Determinants of Eye Lens Transparency. Phil. Trans. R. Soc. B 366, 1250-1264. doi:10.1098/rstb.2010.0302

Beebe, D. C., Silver, M. H., Belcher, K. S., Van Wyk, J. J., Svoboda, M. E., and Zelenka, P. S. (1987). Lentropin, a Protein that Controls Lens Fiber Formation, Is Related Functionally and Immunologically to the Insulin-like Growth Factors. Proc. Natl. Acad. Sci. 84, 2327-2330. doi:10.1073/pnas.84.8.2327

Belecky-Adams, T., Tomarev, S., Li, H. S., Ploder, L., Mcinnes, R. R., Sundin, O., et al. (1997). Pax-6, Prox 1, and Chx10 Homeobox Gene Expression Correlates with Phenotypic Fate of Retinal Precursor Cells. Invest. Ophthalmol. Vis. Sci. 38, 1293-1303.

Berry, V., Pontikos, N., Albarca-Aguilera, M., Plagnol, V., Massouras, A., Prescott, D., et al. (2018). A Recurrent Splice-Site Mutation in EPHA2 Causing Congenital Posterior Nuclear Cataract. Ophthalmic Genet. 39, 236-241. doi:10.1080/13816810.2017.1381977

Biswas, S., Son, A., Yu, Q., Zhou, R., and Lo, W.-K. (2016). Breakdown of Interlocking Domains May Contribute to Formation of Membranous Globules and Lens Opacity in Ephrin-A5-/- Mice. Exp. Eye Res. 145, 130-139. doi:10.1016/j.exer.2015.11.017

Carter, N., Nakamoto, T., Hirai, H., and Hunter, T. (2002). EphrinA1-induced Cytoskeletal Re-organization Requires FAK and P130cas. Nat. Cell Biol 4, 565-573. doi:10.1038/ncb823

Cheng, C., Ansari, M. M., Cooper, J. A., and Gong, X. (2013). EphA2 and Src Regulate Equatorial Cell Morphogenesis during Lens Development. Development 140, 4237-4245. doi:10.1242/dev.100727

Cheng, C. (2021). EphA2 and Ephrin-A5 Guide Eye Lens Suture Alignment and Influence Whole Lens Resilience. Invest. Ophthalmol. Vis. Sci. 62, 3. doi:10. 1167/iovs.62.15.3

Cheng, C., Fowler, V. M., and Gong, X. (2017). EphA2 and Ephrin-A5 Are Not a Receptor-Ligand Pair in the Ocular Lens. Exp. Eye Res. 162, 9-17. doi:10.1016/j. exer.2017.06.016 
Cheng, C., Gao, J., Sun, X., and Mathias, R. T. (2021). Eph-ephrin Signaling Affects Eye Lens Fiber Cell Intracellular Voltage and Membrane Conductance. Front. Physiol. 12, 772276. doi:10.3389/fphys.2021.772276

Cheng, C., and Gong, X. (2011). Diverse Roles of Eph/ephrin Signaling in the Mouse Lens. PLoS One 6, e28147. doi:10.1371/journal.pone.0028147

Cheng, C., Nowak, R. B., Biswas, S. K., Lo, W.-K., Fitzgerald, P. G., and Fowler, V. M. (2016). Tropomodulin 1 Regulation of Actin Is Required for the Formation of Large Paddle Protrusions between Mature Lens Fiber Cells. Invest. Ophthalmol. Vis. Sci. 57, 4084-4099. doi:10.1167/iovs.1619949

Cheng, C., Parreno, J., Nowak, R. B., Biswas, S. K., Wang, K., Hoshino, M., et al. (2019). Age-related Changes in Eye Lens Biomechanics, Morphology, Refractive index and Transparency. Aging 11, 12497-12531. doi:10.18632/ aging.102584

Cheng, C., Wang, K., Hoshino, M., Uesugi, K., Yagi, N., and Pierscionek, B. (2022). EphA2 Affects Development of the Eye Lens Nucleus and the Gradient of Refractive Index. Invest. Ophthalmol. Vis. Sci. 63, 2. doi:10.1167/iovs.63.1.2

Cissé, M., Halabisky, B., Harris, J., Devidze, N., Dubal, D. B., Sun, B., et al. (2011). Reversing EphB2 Depletion Rescues Cognitive Functions in Alzheimer Model. Nature 469, 47-52. doi:10.1038/nature09635

Clevers, H., and Batlle, E. (2006). EphB/EphrinB Receptors and Wnt Signaling in Colorectal Cancer: Figure 1. Cancer Res. 66, 2-5. doi:10.1158/0008-5472.can05-3849

Cooper, M. A., Son, A. I., Komlos, D., Sun, Y., Kleiman, N. J., and Zhou, R. (2008). Loss of Ephrin-A5 Function Disrupts Lens Fiber Cell Packing and Leads to Cataract. Proc. Natl. Acad. Sci. 105, 16620-16625. doi:10.1073/pnas. 0808987105

Darling, T. K., and Lamb, T. J. (2019). Emerging Roles for Eph Receptors and Ephrin Ligands in Immunity. Front. Immunol.10, 1473. doi:10.3389/fimmu. 2019.01473

Dave, A., Martin, S., Kumar, R., Craig, J. E., Burdon, K. P., and Sharma, S. (2016). Epha2 Mutations Contribute to Congenital Cataract through Diverse Mechanisms. Mol. Vis. 22, 18-30.

Dave, A., Craig, J. E., Alamein, M., Skrzypiec, K., Beltz, J., Pfaff, A., et al. (2021). Genotype, Age, Genetic Background, and Sex Influence Epha2-Related Cataract Development in Mice. Invest. Ophthalmol. Vis. Sci. 62, 3. doi:10.1167/iovs.62. 12.3

Dave, A., Laurie, K., Staffieri, S. E., Taranath, D., Mackey, D. A., Mitchell, P., et al. (2013). Mutations in the EPHA2 Gene Are a Major Contributor to Inherited Cataracts in South-Eastern Australia. PLoS One 8, e72518. doi:10.1371/journal. pone. 0072518

Davis, T. L., Walker, J. R., Loppnau, P., Butler-Cole, C., Allali-Hassani, A., and Dhe-Paganon, S. (2008). Autoregulation by the Juxtamembrane Region of the Human Ephrin Receptor Tyrosine Kinase A3 (EphA3). Structure 16, 873-884. doi:10.1016/j.str.2008.03.008

Davy, A., Gale, N. W., Murray, E. W., Klinghoffer, R. A., Soriano, P., Feuerstein, C., et al. (1999). Compartmentalized Signaling by GPI-Anchored Ephrin-A5 Requires the Fyn Tyrosine Kinase to Regulate Cellular Adhesion. Genes Development 13, 3125-3135. doi:10.1101/gad.13.23.3125

Davy, A., and Robbins, S. M. (2000). Ephrin-A5 Modulates Cell Adhesion and Morphology in an Integrin-dependent Manner. EMBO J. 19, 5396-5405. doi:10. 1093/emboj/19.20.5396

Defourny, J. (2019). Eph/ephrin Signalling in the Development and Function of the Mammalian Cochlea. Developmental Biol. 449, 35-40. doi:10.1016/j.ydbio. 2019.02.004

Faber, S. C., Robinson, M. L., Makarenkova, H. P., and Lang, R. A. (2002). Bmp Signaling Is Required for Development of Primary Lens Fiber Cells. Development 129, 3727-3737. doi:10.1242/dev.129.15.3727

Fabes, J., Anderson, P., Brennan, C., and Bolsover, S. (2007). Regenerationenhancing Effects of EphA4 Blocking Peptide Following Corticospinal Tract Injury in Adult Rat Spinal Cord. Eur. J. Neurosci. 26, 2496-2505. doi:10.1111/j. 1460-9568.2007.05859.x

Fang, W. B., Brantley-Sieders, D. M., Hwang, Y., Ham, A.-J. L., and Chen, J. (2008). Identification and Functional Analysis of Phosphorylated Tyrosine Residues within EphA2 Receptor Tyrosine Kinase. J. Biol. Chem. 283, 16017-16026. doi:10.1074/jbc.m709934200

Faoro, L., Singleton, P. A., Cervantes, G. M., Lennon, F. E., Choong, N. W., Kanteti, R., et al. (2010). EphA2 Mutation in Lung Squamous Cell Carcinoma Promotes
Increased Cell Survival, Cell Invasion, Focal Adhesions, and Mammalian Target of Rapamycin Activation. J. Biol. Chem. 285, 18575-18585. doi:10.1074/jbc. m109.075085

Frisén, J., Yates, P. A., Mclaughlin, T., Friedman, G. C., O’leary, D. D. M., and Barbacid, M. (1998). Ephrin-A5 (AL-1/RAGS) Is Essential for Proper Retinal Axon Guidance and Topographic Mapping in the Mammalian Visual System. Neuron 20, 235-243. doi:10.1016/s08966273(00)80452-3

Fu, A. K. Y., Hung, K.-W., Huang, H., Gu, S., Shen, Y., Cheng, E. Y. L., et al. (2014). Blockade of EphA4 Signaling Ameliorates Hippocampal Synaptic Dysfunctions in Mouse Models of Alzheimer's Disease. Proc. Natl. Acad. Sci. USA 111, 9959-9964. doi:10.1073/pnas.1405803111

Gale, N. W., Holland, S. J., Valenzuela, D. M., Flenniken, A., Pan, L., Ryan, T. E., et al. (1996). Eph Receptors and Ligands Comprise Two Major Specificity Subclasses and Are Reciprocally Compartmentalized during Embryogenesis. Neuron 17, 9-19. doi:10.1016/s0896-6273(00)80276-7

Genet, G., Guilbeau-Frugier, C., Honton, B., Dague, E., Schneider, M. D., Coatrieux, C., et al. (2012). Ephrin-B1 Is a Novel Specific Component of the Lateral Membrane of the Cardiomyocyte and Is Essential for the Stability of Cardiac Tissue Architecture Cohesion. Circ. Res. 110, 688-700. doi:10.1161/ circresaha.111.262451

Goichberg, P., Kannappan, R., Cimini, M., Bai, Y., Sanada, F., Sorrentino, A., et al. (2013). Age-associated Defects in EphA2 Signaling Impair the Migration of Human Cardiac Progenitor Cells. Circulation 128, 2211-2223. doi:10.1161/ circulationaha.113.004698

Goldshmit, Y., Spanevello, M. D., Tajouri, S., Li, L., Rogers, F., Pearse, M., et al. (2011). EphA4 Blockers Promote Axonal Regeneration and Functional Recovery Following Spinal Cord Injury in Mice. PLoS One 6, e24636. doi:10.1371/journal.pone.0024636

Gong, X., Agopian, K., Kumar, N. M., and Gilula, N. B. (1999). Genetic Factors Influence Cataract Formation in ?3 Connexin Knockout Mice. Dev. Genet. 24, 27-32. doi:10.1002/(sici)1520-6408(1999)24:1/2<27::aid-dvg4>3.0.co;2-7

Gong, X., Baldo, G. J., Kumar, N. M., Gilula, N. B., and Mathias, R. T. (1998). Gap Junctional Coupling in Lenses Lacking 3 Connexin. Proc. Natl. Acad. Sci. 95, 15303-15308. doi:10.1073/pnas.95.26.15303

Gopal, U., Bohonowych, J. E., Lema-Tome, C., Liu, A., Garrett-Mayer, E., Wang, B., et al. (2011). A Novel Extracellular Hsp90 Mediated Co-receptor Function for LRP1 Regulates EphA2 Dependent Glioblastoma Cell Invasion. PLoS One 6, e17649. doi:10.1371/journal.pone.0017649

Gu, C., and Park, S. (2001). The EphA8 Receptor Regulates Integrin Activity through P110 $\gamma$ Phosphatidylinositol-3 Kinase in a Tyrosine Kinase Activityindependent Manner. Mol. Cell Biol 21, 4579-4597. doi:10.1128/mcb.21.14. 4579-4597.2001

Guo, H., Miao, H., Gerber, L., Singh, J., Denning, M. F., Gilliam, A. C., et al. (2006). Disruption of EphA2 Receptor Tyrosine Kinase Leads to Increased Susceptibility to Carcinogenesis in Mouse Skin. Cancer Res. 66, 7050-7058. doi:10.1158/0008-5472.can-06-0004

Henkemeyer, M., Marengere, L. E., Mcglade, J., Olivier, J. P., Conlon, R. A., Holmyard, D. P., et al. (1994). Immunolocalization of the Nuk Receptor Tyrosine Kinase Suggests Roles in Segmental Patterning of the Brain and Axonogenesis. Oncogene 9, 1001-1014.

Heys, K. R., Cram, S. L., and Truscott, R. J. (2004). Massive Increase in the Stiffness of the Human Lens Nucleus with Age: the Basis for Presbyopia? Mol. Vis. 10, 956-963.

Heys, K. R., Friedrich, M. G., and Truscott, R. J. W. (2007). Presbyopia and Heat: Changes Associated with Aging of the Human Lens Suggest a Functional Role for the Small Heat Shock Protein, a-crystallin, in Maintaining Lens Flexibility. Aging Cell 6, 807-815. doi:10.1111/j.1474-9726.2007.00342.x

Himanen, J.-P., Chumley, M. J., Lackmann, M., Li, C., Barton, W. A., Jeffrey, P. D., et al. (2004). Repelling Class Discrimination: Ephrin-A5 Binds to and Activates EphB2 Receptor Signaling. Nat. Neurosci. 7, 501-509. doi:10.1038/ $\mathrm{nn} 1237$

Himanen, J.-P., Saha, N., and Nikolov, D. B. (2007). Cell-cell Signaling via Eph Receptors and Ephrins. Curr. Opin. Cell Biol. 19, 534-542. doi:10.1016/j.ceb. 2007.08.004

Holmberg, J., Clarke, D. L., and Frisén, J. (2000). Regulation of Repulsion versus Adhesion by Different Splice Forms of an Eph Receptor. Nature 408, 203-206. doi:10.1038/35041577 
Huang, Y., Li, Q., and Wu, F. (2019). Association of EphA2 Gene Polymorphisms With Susceptibility to Age-Related Cataract Among Ethnic Han Chinese From Hubei. Zhonghua Yi Xue Yi Chuan Xue Za Zhi 36, 380-383.

Ireton, R., and Chen, J. (2005). EphA2 Receptor Tyrosine Kinase as a Promising Target for Cancer Therapeutics. Ccdt 5, 149-157. doi:10.2174/ 1568009053765780

Jain, R., Jain, D., Liu, Q., Bartosinska, B., Wang, J., Schumann, D., et al. (2013). Pharmacological Inhibition of Eph Receptors Enhances Glucose-Stimulated Insulin Secretion from Mouse and Human Pancreatic Islets. Diabetologia 56, 1350-1355. doi:10.1007/s00125-013-2877-1

Jiang, J., Wang, Z.-H., Qu, M., Gao, D., Liu, X.-P., Zhu, L.-Q., et al. (2015). Stimulation of EphB2 Attenuates Tau Phosphorylation through PI3K/AktMediated Inactivation of Glycogen Synthase Kinase-3 $\beta$. Sci. Rep. 5, 11765. doi:10.1038/srep11765

Jing, X., Miwa, H., Sawada, T., Nakanishi, I., Kondo, T., Miyajima, M., et al. (2012). Ephrin-A1-mediated Dopaminergic Neurogenesis and Angiogenesis in a Rat Model of Parkinson's Disease. PLoS One 7, e32019. doi:10.1371/journal.pone. 0032019

Jørgensen, C., Sherman, A., Chen, G. I., Pasculescu, A., Poliakov, A., Hsiung, M., et al. (2009). Cell-specific Information Processing in Segregating Populations of Eph Receptor Ephrin-Expressing Cells. Science 326, 1502-1509. doi:10.1126/ science. 1176615

Jun, G., Guo, H., Klein, B. E. K., Klein, R., Wang, J. J., Mitchell, P., et al. (2009). EPHA2 Is Associated with Age-Related Cortical Cataract in Mice and Humans. Plos Genet. 5, e1000584. doi:10.1371/journal.pgen.1000584

Kaczmarek, R., Gajdzis, P., and Gajdzis, M. (2021). Eph Receptors and Ephrins in Retinal Diseases. Int. J. Mol. Sci. 22, 6207. doi:10.3390/ijms22126207

Kania, A., and Klein, R. (2016). Mechanisms of Ephrin-Eph Signalling in Development, Physiology and Disease. Nat. Rev. Mol. Cell Biol 17, 240-256. doi:10.1038/nrm.2015.16

Kaul, H., Riazuddin, S. A., Shahid, M., Kousar, S., Butt, N. H., Zafar, A. U., et al. (2010). Autosomal Recessive Congenital Cataract Linked to EPHA2 in a Consanguineous Pakistani Family. Mol. Vis. 16, 511-517.

Konstantinova, I., Nikolova, G., Ohara-Imaizumi, M., Meda, P., Kucera, T., Zarbalis, K., et al. (2007). EphA-Ephrin-A-Mediated $\beta$ Cell Communication Regulates Insulin Secretion from Pancreatic Islets. Cell 129, 359-370. doi:10. 1016/j.cell.2007.02.044

Koretz, J. F., Cook, C. A., and Kuszak, J. R. (1994). The Zones of Discontinuity in the Human Lens: Development and Distribution with Age. Vis. Res. 34, 2955-2962. doi:10.1016/0042-6989(94)90267-4

Kullander, K., and Klein, R. (2002). Mechanisms and Functions of Eph and Ephrin Signalling. Nat. Rev. Mol. Cell Biol 3, 475-486. doi:10.1038/nrm856

Kuszak, J. R., Mazurkiewicz, M., Jison, L., Madurski, A., Ngando, A., and Zoltoski, R. K. (2006). Quantitative Analysis of Animal Model Lens Anatomy: Accommodative Range Is Related to Fiber Structure and Organization. Vet. Ophthalmol. 9, 266-280. doi:10.1111/j.1463-5224.2006.00506.x

Kuszak, J. R., Zoltoski, R. K., and Sivertson, C. (2004a). Fibre Cell Organization in Crystalline Lenses. Exp. Eye Res. 78, 673-687. doi:10.1016/j.exer.2003.09.016

Kuszak, J. R., Zoltoski, R. K., and Tiedemann, C. E. (2004b). Development of Lens Sutures. Int. J. Dev. Biol. 48, 889-902. doi:10.1387/ijdb.041880jk

Lee, H.-S., Mood, K., Battu, G., Ji, Y. J., Singh, A., and Daar, I. O. (2009). Fibroblast Growth Factor Receptor-Induced Phosphorylation of ephrinB1 Modulates its Interaction with Dishevelled. $M B O C$ 20, 124-133. doi:10.1091/mbc.e08-060662

Lee, S., Shatadal, S., and Griep, A. E. (2016). Dlg-1 Interacts with and Regulates the Activities of Fibroblast Growth Factor Receptors and EphA2 in the Mouse Lens. Invest. Ophthalmol. Vis. Sci. 57, 707-718. doi:10.1167/iovs.15-17727

Li, D., Han, X., Zhao, Z., Lu, Y., and Yang, J. (2021). Functional Analysis of Deleterious EPHA2 SNPs in Lens Epithelial Cells. Mol. Vis. 27, 384-395.

Li, D., Wang, S., Ye, H., Tang, Y., Qiu, X., Fan, Q., et al. (2016). Distribution of Gene Mutations in Sporadic Congenital Cataract in a Han Chinese Population. Mol. Vis. 22, 589-598.

Li, J.-J., Liu, D.-P., Liu, G.-T., and Xie, D. (2009). EphrinA5 Acts as a Tumor Suppressor in Glioma by Negative Regulation of Epidermal Growth Factor Receptor. Oncogene 28, 1759-1768. doi:10.1038/onc.2009.15

Liang, L.-Y., Patel, O., Janes, P. W., Murphy, J. M., and Lucet, I. S. (2019). Eph Receptor Signalling: from Catalytic to Non-catalytic Functions. Oncogene 38, 6567-6584. doi:10.1038/s41388-019-0931-2
Lin, Q., Zhou, N., Zhang, N., and Qi, Y. (2014). Mutational Screening of EFNA5 in Chinese Age-Related Cataract Patients. Ophthalmic Res. 52, 124-129. doi:10. $1159 / 000363139$

Lisabeth, E. M., Falivelli, G., and Pasquale, E. B. (2013). Eph Receptor Signaling and Ephrins. Cold Spring Harb Perspect. Biol. 5, a009159. doi:10.1101/cshperspect. a009159

Lovicu, F. J., and Mcavoy, J. W. (2005). Growth Factor Regulation of Lens Development. Developmental Biol. 280, 1-14. doi:10.1016/j.ydbio.2005.01.020

Lovicu, F. J., and Robinson, M. L. (2004). Development of the Ocular Lens. Cambridge, UK, New York: Cambridge University Press.

Luo, H., Charpentier, T., Wang, X., Qi, S., Han, B., Wu, T., et al. (2011). Efnb1 and Efnb2 Proteins Regulate Thymocyte Development, Peripheral T Cell Differentiation, and Antiviral Immune Responses and Are Essential for Interleukin-6 (IL-6) Signaling. J. Biol. Chem. 286, 41135-41152. doi:10.1074/ jbc.m111.302596

Ma, X., Ma, Z., Jiao, X., and Hejtmancik, J. F. (2017). Functional Non-coding Polymorphism in an EPHA2 Promoter PAX2 Binding Site Modifies Expression and Alters the MAPK and AKT Pathways. Sci. Rep. 7, 9992. doi:10.1038/ s41598-017-10117-3

Marler, K. J. M., Becker-Barroso, E., Martinez, A., Llovera, M., Wentzel, C., Poopalasundaram, S., et al. (2008). A TrkB/EphrinA Interaction Controls Retinal Axon Branching and Synaptogenesis. J. Neurosci. 28, 12700-12712. doi:10.1523/jneurosci.1915-08.2008

Mathias, R. T., Rae, J. L., and Baldo, G. J. (1997). Physiological Properties of the normal Lens. Physiol. Rev. 77, 21-50. doi:10.1152/physrev.1997.77.1.21

Mathias, R. T., Rae, J. L., and Eisenberg, R. S. (1981). The Lens as a Nonuniform Spherical Syncytium. Biophysical J. 34, 61-83. doi:10.1016/s0006-3495(81) 84837-0

Masoodi, T. A., Shammari, S. A., Al-Muammar, M. N., Almubrad, T. M., and Alhamdan, A. A. (2012). Screening and Structural Evaluation of Deleterious Non-Synonymous SNPs of ePHA2 Gene Involved in Susceptibility to Cataract Formation. Bioinformation 8, 562-567.

Matsuoka, H., Obama, H., Kelly, M. L., Matsui, T., and Nakamoto, M. (2005). Biphasic Functions of the Kinase-Defective Ephb6 Receptor in Cell Adhesion and Migration. J. Biol. Chem. 280, 29355-29363. doi:10.1074/ jbc.m500010200

Mcavoy, J. W. (1978a). Cell Division, Cell Elongation and Distribution of $\alpha-, \beta$ - and $\gamma$-crystallins in the Rat Lens. J. Embryol. Exp. Morphol. 44, 149-165. doi:10. 1242/dev.44.1.149

Mcavoy, J. W. (1978b). Cell Division, Cell Elongation and the Co-ordination of Crystallin Gene Expression during Lens Morphogenesis in the Rat. J. Embryol. Exp. Morphol. 45, 271-281. doi:10.1242/dev.45.1.271

Mellitzer, G., Xu, Q., and Wilkinson, D. G. (1999). Eph Receptors and Ephrins Restrict Cell Intermingling and Communication. Nature 400, 77-81. doi:10. 1038/21907

Miao, H., Li, D.-Q., Mukherjee, A., Guo, H., Petty, A., Cutter, J., et al. (2009). EphA2 Mediates Ligand-dependent Inhibition and Ligand-independent Promotion of Cell Migration and Invasion via a Reciprocal Regulatory Loop with Akt. Cancer Cell 16, 9-20. doi:10.1016/j.ccr.2009.04.009

Miao, H., and Wang, B. (2012). EphA Receptor Signaling-Complexity and Emerging Themes. Semin. Cell Developmental Biol. 23, 16-25. doi:10.1016/j. semcdb.2011.10.013

Michael, R., and Bron, A. J. (2011). The Ageing Lens and Cataract: a Model of normal and Pathological Ageing. Phil. Trans. R. Soc. B 366, 1278-1292. doi:10. 1098/rstb.2010.0300

Mitchell, K. J., Pinson, K. I., Kelly, O. G., Brennan, J., Zupicich, J., Scherz, P., et al. (2001). Functional Analysis of Secreted and Transmembrane Proteins Critical to Mouse Development. Nat. Genet. 28, 241-249. doi:10.1038/90074

Moore, K. B., Mood, K., Daar, I. O., and Moody, S. A. (2004). Morphogenetic Movements Underlying Eye Field Formation Require Interactions between the FGF and ephrinB1 Signaling Pathways. Developmental Cell 6, 55-67. doi:10. 1016/s1534-5807(03)00395-2

Naruse-Nakajima, C., Asano, M., and Iwakura, Y. (2001). Involvement of EphA2 in the Formation of the Tail Notochord via Interaction with ephrinA1. Mech. Development 102, 95-105. doi:10.1016/s0925-4773(01)00290-8

Noberini, R., Rubio De La Torre, E., and Pasquale, E. B. (2012). Profiling Eph Receptor Expression in Cells and Tissues. Cell Adhes. Migration 6, 102-156. doi: $10.4161 /$ cam. 19620 
Noren, N. K., and Pasquale, E. B. (2007). Paradoxes of the EphB4 Receptor in Cancer: Figure 1. Cancer Res. 67, 3994-3997. doi:10.1158/0008-5472.can-070525

O'leary, D. D., and Wilkinson, D. G. (1999). Eph Receptors and Ephrins in Neural Development. Curr. Opin. Neurobiol. 9, 65-73. doi:10.1016/s0959-4388(99) 80008-7

Park, E. K., Warner, N., Bong, Y.-S., Stapleton, D., Maeda, R., Pawson, T., et al. (2004). Ectopic EphA4 Receptor Induces Posterior Protrusions via FGF Signaling inXenopusEmbryos. $M B O C$ 15, 1647-1655. doi:10.1091/mbc.e0309-0674

Park, J. E., Son, A. I., Hua, R., Wang, L., Zhang, X., and Zhou, R. (2012). Human Cataract Mutations in EPHA2 SAM Domain Alter Receptor Stability and Function. PLoS One 7, e36564. doi:10.1371/journal.pone.0036564

Parri, M., Buricchi, F., Giannoni, E., Grimaldi, G., Mello, T., Raugei, G., et al. (2007). EphrinAl Activates a Src/focal Adhesion Kinase-Mediated Motility Response Leading to Rho-dependent Actino/myosin Contractility. J. Biol. Chem. 282, 19619-19628. doi:10.1074/jbc.m701319200

Pasquale, E. B. (2005). Eph Receptor Signalling Casts a Wide Net on Cell Behaviour. Nat. Rev. Mol. Cell Biol 6, 462-475. doi:10.1038/nrm1662

Pasquale, E. B. (2010). Eph Receptors and Ephrins in Cancer: Bidirectional Signalling and beyond. Nat. Rev. Cancer 10, 165-180. doi:10.1038/nrc2806

Pasquale, E. B. (2008). Eph-ephrin Bidirectional Signaling in Physiology and Disease. Cell 133, 38-52. doi:10.1016/j.cell.2008.03.011

Pasquale, E. B. (2004). Eph-ephrin Promiscuity Is Now crystal clear. Nat. Neurosci. 7, 417-418. doi:10.1038/nn0504-417

Pasquale, E., Deerinck, T., Singer, S., and Ellisman, M. (1992). Cek5, a Membrane Receptor-type Tyrosine Kinase, Is in Neurons of the Embryonic and Postnatal Avian Brain. J. Neurosci. 12, 3956-3967. doi:10.1523/jneurosci.12-10-03956. 1992

Patel, N., Anand, D., Monies, D., Maddirevula, S., Khan, A. O., Algoufi, T., et al. (2017). Novel Phenotypes and Loci Identified through Clinical Genomics Approaches to Pediatric Cataract. Hum. Genet. 136, 205-225. doi:10.1007/ s00439-016-1747-6

Piatigorsky, J. (1981). Lens Differentiation in Vertebrates. Differentiation 19, 134-153. doi:10.1111/j.1432-0436.1981.tb01141.x

Picco, V., Hudson, C., and Yasuo, H. (2007). Ephrin-Eph Signalling Drives the Asymmetric Division of Notochord/neural Precursors in Ciona Embryos. Development 134, 1491-1497. doi:10.1242/dev.003939

Pitulescu, M. E., and Adams, R. H. (2010). Eph/ephrin Molecules-A Hub for Signaling and Endocytosis. Genes Dev. 24, 2480-2492. doi:10.1101/gad. 1973910

Poliakov, A., Cotrina, M., and Wilkinson, D. G. (2004). Diverse Roles of Eph Receptors and Ephrins in the Regulation of Cell Migration and Tissue Assembly. Developmental Cell 7, 465-480. doi:10.1016/j.devcel.2004. 09.006

Rivera, C., Yamben, I. F., Shatadal, S., Waldof, M., Robinson, M. L., and Griep, A. E. (2009). Cell-autonomous Requirements forDlg-1for Lens Epithelial Cell Structure and Fiber Cell Morphogenesis. Dev. Dyn. 238, 2292-2308. doi:10. $1002 /$ dvdy. 22036

Salvucci, O., and Tosato, G. (2012). Essential Roles of EphB Receptors and EphrinB Ligands in Endothelial Cell Function and Angiogenesis. Adv. Cancer Res. 114, 21-57. doi:10.1016/b978-0-12-386503-8.00002-8

Sella, R., and Afshari, N. A. (2019). Nutritional Effect on Age-Related Cataract Formation and Progression. Curr. Opin. Ophthalmol. 30, 63-69. doi:10.1097/ icu. 0000000000000537

Shaw, A., Lundin, V., Petrova, E., Fördős, F., Benson, E., Al-Amin, A., et al. (2014). Spatial Control of Membrane Receptor Function Using Ligand Nanocalipers. Nat. Methods 11, 841-846. doi:10.1038/nmeth.3025

Shentu, X. C., Zhao, S. J., Zhang, L., and Miao, Q. (2013). A Novel p.R890C Mutation in EPHA2 Gene Associated with Progressive Childhood Posterior Cataract in a Chinese Family. Int. J. Ophthalmol. 6, 34-38. doi:10.3980/j.issn. 2222-3959.2013.01.07

Shi, Y., De Maria, A., Bennett, T., Shiels, A., and Bassnett, S. (2012). A Role forEpha2in Cell Migration and Refractive Organization of the Ocular Lens. Invest. Ophthalmol. Vis. Sci. 53, 551-559. doi:10.1167/iovs.11-8568

Shiels, A., Bennett, T. M., Knopf, H. L., Maraini, G., Li, A., Jiao, X., et al. (2008). The EPHA2 Gene Is Associated with Cataracts Linked to Chromosome 1p. Mol. Vis. $14,2042-2055$.
Shiels, A., and Hejtmancik, J. F. (2017). Mutations and Mechanisms in Congenital and Age-Related Cataracts. Exp. Eye Res. 156, 95-102. doi:10.1016/j.exer.2016. 06.011

Son, A. I., Cooper, M. A., Sheleg, M., Sun, Y., Kleiman, N. J., and Zhou, R. (2013). Further Analysis of the Lens of Ephrin-A5-/- Mice: Development of Postnatal Defects. Mol. Vis. 19, 254-266.

Spanevello, M. D., Tajouri, S. I., Mirciov, C., Kurniawan, N., Pearse, M. J., Fabri, L. J., et al. (2013). Acute Delivery of EphA4-Fc Improves Functional Recovery after Contusive Spinal Cord Injury in Rats. J. Neurotrauma 30, 1023-1034. doi:10.1089/neu.2012.2729

Ståhl, S., Mm Branca, R., Efazat, G., Ruzzene, M., Zhivotovsky, B., Lewensohn, R., et al. (2011). Phosphoproteomic Profiling of NSCLC Cells Reveals that Ephrin B3 Regulates Pro-survival Signaling through Akt1-Mediated Phosphorylation of the EphA2 Receptor. J. Proteome Res. 10, 2566-2578. doi: $10.1021 / \mathrm{pr} 200037 \mathrm{u}$

Stephen, L. J., Fawkes, A. L., Verhoeve, A., Lemke, G., and Brown, A. (2007). A Critical Role for the EphA3 Receptor Tyrosine Kinase in Heart Development. Developmental Biol. 302, 66-79. doi:10.1016/j.ydbio.2006.08.058

Sundaresan, P., Ravindran, R. D., Vashist, P., Shanker, A., Nitsch, D., Talwar, B., et al. (2012). EPHA2 Polymorphisms and Age-Related Cataract in India. PLoS One 7, e33001. doi:10.1371/journal.pone.0033001

Takemoto, M., Fukuda, T., Sonoda, R., Murakami, F., Tanaka, H., and Yamamoto, N. (2002). Ephrin-B3-EphA4 Interactions Regulate the Growth of Specific Thalamocortical Axon Populationsin Vitro. Eur. J. Neurosci. 16, 1168-1172. doi:10.1046/j.1460-9568.2002.02166.x

Tan, W., Hou, S., Jiang, Z., Hu, Z., Yang, P., and Ye, J. (2011). Association of EPHA2 Polymorphisms and Age-Related Cortical Cataract in a Han Chinese Population. Mol. Vis. 17, 1553-1558.

Taylor, H., Campbell, J., and Nobes, C. D. (2017). Ephs and Ephrins. Curr. Biol. 27, R90-R95. doi:10.1016/j.cub.2017.01.003

Uwineza, A., Kalligeraki, A. A., Hamada, N., Jarrin, M., and Quinlan, R. A. (2019). Cataractogenic Load - A Concept to Study the Contribution of Ionizing Radiation to Accelerated Aging in the Eye Lens. Mutat. Research/Reviews Mutat. Res. 779, 68-81. doi:10.1016/j.mrrev.2019. 02.004

Wang, H. U., Chen, Z.-F., and Anderson, D. J. (1998). Molecular Distinction and Angiogenic Interaction between Embryonic Arteries and Veins Revealed by Ephrin-B2 and its Receptor Eph-B4. Cell 93, 741-753. doi:10.1016/s00928674(00)81436-1

Wang, Q., Mcavoy, J. W., and Lovicu, F. J. (2010). Growth Factor Signaling in Vitreous Humor-Induced Lens Fiber Differentiation. Invest. Ophthalmol. Vis. Sci. 51, 3599-3610. doi:10.1167/iovs.09-4797

Weeber, H. A., Eckert, G., Pechhold, W., and Van Der Heijde, R. G. L. (2007). Stiffness Gradient in the Crystalline Lens. Graefes Arch. Clin. Exp. Ophthalmol. 245, 1357-1366. doi:10.1007/s00417-007-0537-1

Wiesner, S., Wybenga-Groot, L. E., Warner, N., Lin, H., Pawson, T., Forman-Kay, J. D., et al. (2006). A Change in Conformational Dynamics Underlies the Activation of Eph Receptor Tyrosine Kinases. EMBO J. 25, 4686-4696. doi:10. 1038/s.emboj.7601315

World Health Organization (2019). World Report on Vision.

Wu, Z., Ashlin, T. G., Xu, Q., and Wilkinson, D. G. (2019). Role of Forward and Reverse Signaling in Eph Receptor and Ephrin Mediated Cell Segregation. Exp. Cell Res. 381, 57-65. doi:10.1016/j.yexcr.2019.04.040

Xu, Q., Alldus, G., Holder, N., and Wilkinson, D. G. (1995). Expression of Truncated Sek-1 Receptor Tyrosine Kinase Disrupts the Segmental Restriction of Gene Expression in the Xenopus and Zebrafish Hindbrain. Development 121, 4005-4016. doi:10.1242/dev.121.12.4005

Yang, J., Luo, J., Zhou, P., Fan, Q., Luo, Y., and Lu, Y. (2013). Association of the Ephreceptor Tyrosinekinase-Type A2 (EPHA2) Gene Polymorphism rs3754334 With Age-Related Cataract Risk: A Meta-Analysis. PLoS One 8, e71003.

Yang, N.-Y., Pasquale, E. B., Owen, L. B., and Ethell, I. M. (2006). The EphB4 Receptor-Tyrosine Kinase Promotes the Migration of Melanoma Cells through Rho-Mediated Actin Cytoskeleton Reorganization. J. Biol. Chem. 281, 32574-32586. doi:10.1074/jbc.m604338200

Yates, C. M., and Sternberg, M. J. E. (2013). The Effects of Non-synonymous Single Nucleotide Polymorphisms (nsSNPs) on Protein-Protein Interactions. J. Mol Biol. 425, 3949-3963. doi:10.1016/j.jmb.2013.07.012 
Zaharan, N. L., Muhamad, N. H., Jalaludin, M. Y., Su, T. T., Mohamed, Z., Mohamed, M. N. A. H., et al. (2018). Non-Synonymous Single-Nucleotide Polymorphisms and Physical Activity Interactions on Adiposity Parameters in Malaysian Adolescents. Front. Endocrinol. (Lausanne) 9, 209. doi:10.3389/fendo.2018.00209

Zantek, N. D., Azimi, M., Fedor-Chaiken, M., Wang, B., Brackenbury, R., and Kinch, M. S. (1999). E-cadherin Regulates the Function of the EphA2 Receptor Tyrosine Kinase. Cell Growth Differ 10, 629-638.

Zhai, Y., Zhu, S., Li, J., and Yao, K. (2019). A Novel Human Congenital Cataract Mutation in EPHA2 Kinase Domain (p.G668D) Alters Receptor Stability and Function. Invest. Ophthalmol. Vis. Sci. 60, 4717-4726. doi:10.1167/iovs.1927370

Zhang, T., Hua, R., Xiao, W., Burdon, K. P., Bhattacharya, S. S., Craig, J. E., et al. (2009). Mutations of the EPHA2 Receptor Tyrosine Kinase Gene Cause Autosomal Dominant Congenital Cataract. Hum. Mutat. 30, E603-E611. doi:10.1002/humu.20995

Zhang, X. Q., Takakura, N., Oike, Y., Inada, T., Gale, N. W., Yancopoulos, G. D., et al. (2001). Stromal Cells Expressing Ephrin-B2 Promote the Growth and Sprouting of Ephrin-B2(+) Endothelial Cells. Blood 98, 1028-1037. doi:10. 1182/blood.v98.4.1028

Zhao, C., Irie, N., Takada, Y., Shimoda, K., Miyamoto, T., Nishiwaki, T., et al. (2006). Bidirectional ephrinB2-EphB4 Signaling Controls Bone Homeostasis. Cell Metab 4, 111-121. doi:10.1016/j.cmet.2006.05.012

Zhou, Y., Bennett, T. M., Ruzycki, P. A., and Shiels, A. (2021). Mutation of the EPHA2 Tyrosine-Kinase Domain Dysregulates Cell Pattern Formation and
Cytoskeletal Gene Expression in the Lens. Cells 10, 2606. doi:10.3390/ cells 10102606

Zhou, Y., and Shiels, A. (2018). Epha2 and Efna5 Participate in Lens Cell PatternFormation. Differentiation 102, 1-9. doi:10.1016/j.diff.2018.05.002

Zhou, Y., Yamada, N., Tanaka, T., Hori, T., Yokoyama, S., Hayakawa, Y., et al. (2015). Crucial Roles of RSK in Cell Motility by Catalysing Serine Phosphorylation of EphA2. Nat. Commun. 6, 7679. doi:10.1038/ncomms8679

Conflict of Interest: The authors declare that the research was conducted in the absence of any commercial or financial relationships that could be construed as a potential conflict of interest.

Publisher's Note: All claims expressed in this article are solely those of the authors and do not necessarily represent those of their affiliated organizations, or those of the publisher, the editors and the reviewers. Any product that may be evaluated in this article, or claim that may be made by its manufacturer, is not guaranteed or endorsed by the publisher.

Copyright (c) 2022 Murugan and Cheng. This is an open-access article distributed under the terms of the Creative Commons Attribution License (CC BY). The use, distribution or reproduction in other forums is permitted, provided the original author(s) and the copyright owner(s) are credited and that the original publication in this journal is cited, in accordance with accepted academic practice. No use, distribution or reproduction is permitted which does not comply with these terms. 